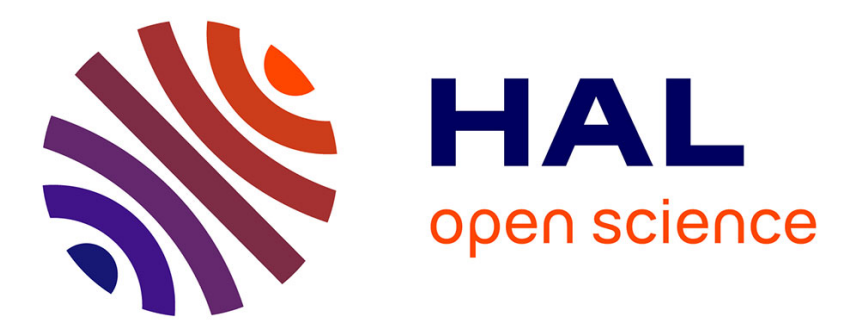

\title{
The trade-growth nexus in the developing countries: a quantile regression approach
}

Gilles Dufrenot, Valerie Mignon, Charalambos Tsangarides

\section{To cite this version:}

Gilles Dufrenot, Valerie Mignon, Charalambos Tsangarides. The trade-growth nexus in the developing countries: a quantile regression approach. Review of World Economics, 2010, 146 (4), pp.731-761. 10.1007/s10290-010-0067-5 . hal-00624420

\section{HAL Id: hal-00624420 \\ https://hal.science/hal-00624420}

Submitted on 17 Sep 2011

HAL is a multi-disciplinary open access archive for the deposit and dissemination of scientific research documents, whether they are published or not. The documents may come from teaching and research institutions in France or abroad, or from public or private research centers.
L'archive ouverte pluridisciplinaire HAL, est destinée au dépôt et à la diffusion de documents scientifiques de niveau recherche, publiés ou non, émanant des établissements d'enseignement et de recherche français ou étrangers, des laboratoires publics ou privés. 


\title{
The trade-growth nexus in the developing countries: a quantile regression approach ${ }^{1}$
}

\author{
Fifth revised version - ROWE-D-09-00171
}

\begin{abstract}
This paper applies quantile regression techniques to investigate how the impact of trade openness on the growth rate of per capita income varies with the conditional distribution of growth. Using formal robustness analyses, we first identify robust variables affecting economic growth (investment, government balance, terms of trade, inflation, and population growth) which we then use as controls in the quantile regression estimations. Our findings suggest a heterogeneous trade-growth nexus: for both the short and the long run, the effect of openness on growth is higher in countries with low growth rates compared to those with high growth rates.
\end{abstract}

JEL Classification: C23; F13; 011.

Keywords: Quantile regression, trade-growth nexus, developing countries.

\footnotetext{
${ }^{1}$ We would like to thank the editor and an anonymous referee for very useful comments and suggestions. We also thank seminar participants at CEPII, DEFI, CERDI, WAEMU Commission, and particularly acknowledge suggestions by Jean-Louis Combes, Patrick Guillaumont, Gilles Nancy and Gilles Sanon.
} 


\section{Introduction}

The quest for growth - particularly in the developing and emerging countries - has resulted in a large volume of the literature since the early 1990s. Until the last two decades, it was a widely accepted view that among the driving factors of long-run growth, trade plays an important role in shaping economic and social performance. Policy recommendations based on export-led growth and trade liberalization have been at the heart of poverty reduction strategies for many years, and developing countries were encouraged to reduce trade barriers in order to benefit from their comparative advantage. Theoretical foundations of the positive links between trade openness strategies, growth and poverty reduction come at least from two sources. On the one hand, the neoclassical approach explains the gains from trade liberalization by comparative advantages, be they in the form of resource endowment (as in the Heckscher-Ohlin model) or differences in technology (as shown by the Ricardian model). On the other hand, the endogenous growth literature asserts that trade openness positively affects per capita income and growth through economies of scale and technological diffusion between countries. ${ }^{2}$

The empirical investigation of these theoretical foundations points to a large variation in the distribution of the benefits from trade openness to growth or to economic development. Some Asian and Latin American countries that managed to develop export-based strategies have been rewarded with high economic growth, while African countries have remained trailing behind despite efforts to emulate the export-led growth model. To explain this, one strand of the literature emphasizes the conditional aspect of the trade-growth link: trade openness may not be conducive to growth in the absence of an appropriate economic, social and political environment. Following North (1990), some argue that institutional arrangements (governance and policies), market institutions (bureaucracy and competition) and social norms determine the degree to which trade openness contributes to higher income and growth (see, among others, Dollar and Kraay (2003)). Others, including Krugman (1990), state that the expansion of growth augments a country's income once the increase in the determinants of growth (capital, labor, education, and infrastructure) are taken into account, suggesting the possibility of various trade-growth relationships under different economic and social environments.

The hypothesis of a heterogeneous trade-growth nexus conditional on the country's structural characteristics has received some theoretical support. For instance, drawing on the experience of some developing countries, Devarajan and Rodrik (1989) use a general equilibrium model to show that trade liberalization can be either welfare-augmenting or welfare-reducing in the presence of imperfect competition or increasing returns. Also, Young (1991) shows that growth can be higher for a country under autarky than under free trade, and Rassekh (2004) provides an overview of theoretical models showing that growth effects from trade openness can be either positive or negative across countries. Despite the theoretical interest, however, empirical investigation of this hypothesis has not yet received enough attention.

In this paper, we pay special attention to the question of heterogeneity of the trade-growth link. More specifically, we test the conjecture that differences in the trade-growth nexus originate from fulfilled or unfulfilled internal preconditions, most of which relate to the domestic factors of economic growth (productive infrastructure, human capital, efficient investment, and factor productivity). Various methods have been used to account for non-linearities in the context of the trade-growth relationship,

\footnotetext{
${ }^{2}$ Examples of seminal papers on these topics are Grossman and Helpman (1991a, 1991b), Rivera-Batiz and Romer (1991), Barro and Sala-í-Martin (1997), Sala-í-Martin (1997), and Eaton and Kortum (1999).
} 
including using interaction terms, threshold models, and quantile regressions. Following Durlauf and Johnson (1995) and Hansen (2000), Papageorgiou (2002) uses a data-sorting method to allow the data to endogenously select regimes using different variables. He finds that openness is a threshold variable permitting to classify middle-income countries into two growth regimes characterized by two different models. Chang et al. (2009) investigate the trade-growth nexus by including interaction terms of openness and proxies of various growth determinants such as educational investment, financial depth, and public infrastructure. They find that the growth effects of openness may be enhanced by certain complementary reforms. In this paper, we account for the heterogeneity of the trade-growth link by employing a quantile regression analysis, which allows the investigation of the openness-growth nexus at various points on the conditional growth distribution to identify possible differences in the trade elasticities of high- and low-growth countries. Compared to the other methods, quantile regressions may be viewed as a complementary means to account for heterogeneity across countries in the sense that this approach allows the coefficients of the explanatory variablesamong which openness - to differ depending on non-modeled growth determinants, as opposed to depending on single factors represented by individual interaction terms.

While a vast body of empirical literature exists on openness and growth, to the best of our knowledge, only Foster (2008) applies quantile regressions analysis in the context of the trade-growth nexus. ${ }^{3}$ In this paper, we contribute to the literature in three ways. First, we use openness rather than liberalization to proxy trade in the quantile regressions investigating the trade-growth nexus. Compared to a trade liberalization dummy, which aims to capture a change in openness, our measure of openness - based on the ratio of the sum of exports and imports to GDP - is intended to capture the level of openness. Retaining this measure allows us to complement the empirical literature which mainly uses indicator variables of trade liberalization to proxy trade. Second, to address concerns about model uncertainty stemming from the lack of clear theoretical guidance concerning the choice of growth regressors, we use Bayesian Model Averaging (BMA) to identify robust growth determinants which are then included as controls in the quantile growth regressions. Finally, we address the concerns of inconsistent estimates due to endogeneous variables that are incorrectly considered as exogenous by including appropriate instruments.

We examine the relationship between openness and growth using annual data for 75 developing countries in the period of 1980-2006. Our results suggest that conditioning on the identified robust determinants, the impact of trade on growth varies depending on the location of a country on the distribution of per capita growth; openness has a higher impact on growth among low-growth countries relative to high-growth countries. In addition, we find evidence of significantly larger shortrun and long-run effects for the same group of countries. Both of these results support the idea of a heterogeneous trade-growth nexus among the developing countries. Finally, we identify significant changes in the conditional growth distribution as a response to openness shocks. Overall, our findings suggest that while low-growth countries can benefit the most from openness in the long run, they are also likely to suffer the most from short-run effects of openness.

\footnotetext{
${ }^{3}$ Foster (2008) proxies trade using a liberalization dummy variable and uses a growth model specification that is rather ad hoc and ignores model uncertainty. Within the context of growth, Cunningham (2003), and Mello and Perrelli (2003) examine convergence and the effects of growth determinants/policy variables using quantile regressions. Quantile regressions are also employed by Barreto and Hughes (2004) to identify the determinants of growth for under-achieving countries relative to those for over-achievers, and Osborne (2006) who uses panels of five-year averages to examine how a number of growth determinants (including openness) differ across quantiles.
} 
The remainder of the paper is structured as follows. Section 2 discusses the empirical framework by presenting the model and the econometric methodology in the context of the quantile regression approach, and the robustness analysis to identify the growth determinants. Section 3 presents the results from the quantile regressions and offers some policy recommendations. Section 4 contains some robustness tests and sensitivity analysis. Section 5 concludes.

\section{The empirical framework}

Our empirical investigation is centered around the specification of a growth regression which includes trade openness and other determinants as explanatory variables. This equation applies to a pool of countries $i(i=1, \ldots, N)$ observed over $T$ periods $(t=1, \ldots, T)$ as follows:

$$
\Delta \log \left(y_{i t}\right)=\mathbf{c}_{i}+\alpha \text { OPEN }_{i t}+\Omega \mathbf{Z}_{i t}+\varepsilon_{i t}
$$

where $y$ is the real GDP per capita, OPEN is an indicator of trade openness and $\mathbf{Z}$ is a vector of contemporaneous and lagged values of growth determinants (including the lagged value of $y$ ). The double index $i t$ refers to a country $i$ observed at time $t$, and $\mathbf{c}$ is a vector of individual fixed effects. ${ }^{4}$

We are interested in estimating Equation (1) in a way that identifies differences in the response of the per capita income growth rate to changes in trade openness ${ }^{5}$ and other growth determinants for countries at various points of the income distribution. First, the application of quantile regression techniques allows the investigation of possible parameter heterogeneity across the conditional distribution of growth rates. Second, to address the concern of model uncertainty in the specification of the variables $\mathbf{Z}$ in Equation (1), we conduct a formal robustness analysis using BMA. Finally, we address the endogeneity of the explanatory variables. We present all three parts of our approach below.

\subsection{Quantile regression principle}

The majority of the current empirical literature on the trade-growth nexus-based on ordinary least squares (OLS), generalized least squares (GLS), instrumental variables (IV), generalized method of moments (GMM), or matching estimators - assumes parameter homogeneity. ${ }^{6}$

Consider the linear model:

$$
Y_{i t}=\mathbf{X}_{i t}^{\prime} \beta+v_{i t}
$$

where $Y$ is the dependent variable and $\mathbf{X}$ is a vector of explanatory variables. The essential feature of a regression analysis is to examine the manner in which a set of explanatory variables affects the conditional distribution of a dependent variable. In the classical econometric techniques (OLS, GLS, IV, and GMM), the component around which the dependent variable randomly fluctuates is the

\footnotetext{
${ }^{4}$ We do not include time dummies since our equation is estimated as an error-correction model. Accordingly, the cyclical variations are captured by the short-run dynamic components.

${ }^{5}$ In our empirical application, the trade openness variable is measured by bilateral trade forecasted from a gravity equation. By this construction, this variable captures the multidimensional nature of openness by taking into account transportation costs, trade barriers, and the rest of the usual determinants.

${ }^{6}$ For a review of empirical works on trade and growth, refer to Billmeier and Nannicini (2007).
} 
conditional mean $E Y / \mathbf{X}, \beta$. However, assuming homogeneous elasticities across countries could lead to an over-fitting of conclusions based on the global population of economies to a particular subset of interest. Speaking differently, an empirical regularity found (say, a beneficial impact of openness on growth) may differ in its relevance for certain subsets of countries if there is a heterogeneity bias underlying the data.

In our investigation, the use of quantile regressions improves upon the usual techniques by uncovering patterns in which the effect of trade openness, conditional on other growth determinants, varies across countries. Unlike the classical approach - which amounts to estimating the conditional mean of the conditional distribution of $Y$ - the quantile estimator is employed on different quantiles of the conditional distribution. ${ }^{7}$

Let $F(y)$ be the cumulated distribution function of $Y$. The $\theta^{\text {th }}$ quantile of $Y$ is defined as the smallest $y$ satisfying $F \geq \theta$. In a regression context, it can be shown that finding $\theta$ amounts to obtaining the following estimator of $\beta$ :

$$
\hat{\beta}_{\theta}=\arg \min _{\beta_{\theta}} \sum_{i=1}^{T} H_{\theta} \stackrel{-}{-} H_{\theta}\left(v_{i t}\right)=\theta \mathbf{v}_{i t}^{+}+\mathbf{1}-\theta \underline{\mathbf{v}}_{i t}^{-}
$$

where $\mathbf{v}_{i t}^{+}$is the vector of residuals with positive values and 0 otherwise, $\mathbf{v}_{i t}^{-}$is the vector of negative residuals and 0 otherwise. Therefore, we have as many estimators of $\beta$ (and quantile regression estimates $\beta$ ) as values of $\theta \in(0,1)$ by changing the "representative" individual. The latter can be the mean (as in OLS), the median $(\theta=0.5)$ or any other quantile.

Koenker and Bassett (1978) derive asymptotic normality results for the quantile regression and show that:

$$
\sqrt{T} \boldsymbol{\beta}_{\theta}-\beta_{\theta} \approx N \boldsymbol{\alpha}, \theta(1-\theta) s(\theta)^{2} J^{-1}
$$

where

$$
\begin{gathered}
J=\lim _{T \rightarrow \infty} \mathbf{X}^{\prime} \mathbf{X} / T \\
s \boldsymbol{Q}^{-}=1 / f\left(F^{-1}(\theta)\right)
\end{gathered}
$$

While the estimation of $\beta$ is quite simple and requires the use of simplex algorithms (see D'Orey and Koenker (1987)), the estimate of the residual variance and the standard error of the estimated parameters is more complicated, since it requires the estimation of the unknown probability distribution function of $y$ and its derivative. The latter is necessary to estimate the quantile density function $s \boldsymbol{\theta}$, also called the sparsity function. Computation of the coefficient covariance matrices is an important part of quantile regression analysis and various approaches are available: bootstrap resampling methods, direct methods based on Siddiqui difference coefficients and kernel density (see Koenker and Bassett (1982), and Koenker (1994)).

\footnotetext{
${ }^{7}$ Quantile regressions have been introduced by Koenker and Bassett (1978). See also the references quoted in Footnote 9.
} 
We use the quantile regression methodology to estimate (1) and investigate the possibility of differences between the elasticities of high- and low-growth countries. From a methodological viewpoint, Koenker (2004) points out that quantile regressions in panel data with a large number of cross-sectional units and relatively short time periods may result in a large number of individual fixed effects and can alter the estimation of the other parameters of interest. Various methods have been proposed to address this problem. For instance, Chay (1995) suggests implementing quantile regressions on several cross-sections, and Koenker (2004) proposes the use of penalty methods in order to regularize or shrink these individual effects towards a common value. In this paper, we adopt a methodology that combines the preceding procedures by shrinking the individual fixed effects to a subset of them that are significant. This implies considering many different combinations of the fixed effects, dropping those which are significant and keeping the others in the regressions yielding the highest "corrected" pseudo-R-squares (that is a pseudo-R-squares penalized by the number of regressors). This iterative procedure yields better results than shrinking all the fixed effects to a common intercept.

We pay particular attention to the selection of the control variables $\mathbf{Z}$ in (1), as well as concerns of possible endogeneity of the regressors (see Sections 2.2 and 2.3 below, respectively). In particular, we are interested in the causal link between openness and growth, more specifically in the behavior of the coefficient $\alpha$ in Equation (1) for three quantiles $(\theta=0.25,0.5,0.75)$. In addition, we examine the manner in which the trade-growth nexus differs at the tails of the conditional distribution by considering graphs corresponding to different quantiles between the 10th and the $90^{\text {th }}$. Finally, we investigate how openness alters the conditional distribution of growth in developing countries, by simulating an openness shock and comparing the growth probability density function using the original data and the distribution of the forecasted level of growth that emerges following the simulated shock. ${ }^{8}$

\subsection{Selection of the control variables}

Model uncertainty — initially pointed out by Leamer (1978) and later elaborated by Brock and Durlauf (2001) - arises because the lack of clear theoretical guidance and trade-offs on the choice of regressors result in a broad number of possible specifications, and often contradictory conclusions. A coherent mechanism to address the problem of model uncertainty is provided by BMA. ${ }^{9}$ BMA involves averaging over all possible combinations of predictors when making inferences about the quantities of interest. Unlike the classical approach which conditions on a single model, in BMA no single model is assumed to be the "true" model. Instead, all possible models are assigned different probabilities based on the researcher's prior beliefs using the posterior model probabilities as weights. The lack of consensus on the key determinants of growth has recently led some scholars to formally incorporate model uncertainty through the use of BMA in the empirical growth analysis. Fernández, Ley and Steel (2001a) (henceforth, FLS), Brock and Durlauf (2001), Brock et al. (2003), Sala-1́Martin, Doppelhofer, and Miller (2004) (henceforth, SDM), Tsangarides (2005), Masanjala and Papageorgiou (2008), and Mirestean and Tsangarides (2009) have used BMA techniques to investigate cross-country growth determinants.

\footnotetext{
${ }^{8}$ This technique allows the examination of how a uniform change in trade openness can affect the dispersion of economic growth. For surveys of quantile regression methods, see Buchinsky (1998), Koenker and Hallock (2001), and Koenker (2005).

${ }^{9}$ Seminal contributions to BMA include those of Raftery (1995), and Raftery et al. (1997).
} 
We apply both the FLS and SDM techniques to identify robust growth determinants $\mathbf{Z}$ for (1). Note that the analysis is implemented at the conditional mean of the distribution-and not on each quantile - because our main purpose is the identification of the differentiated effect of openness on growth given the same set of explanatory variables across the quantiles. ${ }^{10}$ If trade openness is found to be a robust determinant of growth and if the control variables are allowed to differ across countries and/or quantiles, it would be very difficult to identify whether we are finding different effects of openness on growth due to the presence of different control variables, or the impact of openness. ${ }^{11}$

To identify the robust growth determinants, we use the data set of Tsangarides (2005) which covers a cross-section of countries using data on five-year averages within the period 1960-2005. This data set is different to that used in the later regression analysis in two ways, namely, the longer time period (1960-2005 versus 1980-2006) and the use of five-year averages rather than the annual data we employ in our regression analysis. The use of these different data sets deserves some justification. The use of the longer time-series for the BMA analysis gives us a data set with more variation both across and within countries, which should help in obtaining the true robust growth determinants. The use of five-year averages rather than annual data is intended to remove the importance of shocks from the data, allowing us to concentrate on the underlying determinants of growth. In our regression analysis however we use annual data, which allows us to include dynamic effects in our model and account for endogeneity. Given that one may expect that the determinants of short- (e.g., annual) and medium-run (e.g., five-year averaged) growth are likely to be similar, the use of data at these different frequencies need not be seen as a crucial problem in our study.

We consider two simulations of 22 potential explanatory variables to arrive to a set of robust growth determinants. The two simulations differ (marginally) in the set of determinants to further examine robustness, mainly the inclusion of the Sub-Saharan Africa dummy, which is an attempt to control for potential heterogeneity in the sample. The list of robust variables is virtually unchanged between the two simulations.

Table 7 in Appendix A presents the results of our robustness simulations. A variable is identified as a robust determinant if (i) the data favors its inclusion (e.g., its posterior inclusion probability is higher than 0.50 , the unconditional prior for each variable), and (ii) the estimated coefficients have stable signs (e.g., the "sign certainty" is above 0.90). Appendix A provides some background on BMA and outlines our methodology, while Appendix B gives a description of the determinants used and their sources. The results can be summarized as follows.

First, we identify a robust effect of the "Solow determinants", namely, population growth and investment, and the initial level of per capita GDP capturing conditional convergence, as well as a few policy variables, such as trade openness and the government's balance as share of GDP. It is indeed reassuring that the openness variable (our key variable of interest) is identified as a robust

\footnotetext{
${ }^{10}$ In addition to the BMA and the Extreme Bounds Analysis, other methods have been proposed in the literature to identify robust determinants and are based on model selection criteria. See, e.g., Hendry and Krolzig (2004) or on the Least Absolute Shrinkage and Selection Operator (LASSO) estimator Zou (2006).

${ }^{11}$ Note that Barreto and Hughes (2004) and Crespo-Cuaresma et al. (2009) aim at investigating how the set of robust growth determinants varies across quantiles. In particular, Barreto and Hughes (2004) consider an extreme bounds analysis similar to Levine and Renelt (1992) to show that the determinants of growth are not the same for under-performing countries and over-achieving ones. Crespo-Cuaresma et al. (2009) investigate growth across European regions and show that, even if a determinant is robust across regions, its impact on growth may considerably differ across the quantiles.
} 
determinant, which further underlines its importance. In addition, while we identify life expectancy, the tropical area dummy, and ethnicity as robust, in the end, we drop these three variables because of data availability and due to the fact that some represent fixed effects. Finally, there is tentative robustness evidence for inflation rate and terms of trade (as in some cases conclusions vary with the choice of the prior), but we chose to keep them in the list of robust variables. ${ }^{12}$ In the end, we retain seven variables, namely initial per capita GDP, log of real investment as share of GDP, government's balance in percentage of GDP, openness, population growth, terms of trade growth, and inflation rate.

\subsection{Endogeneity of the explanatory variables}

A typical concern in growth regressions is the issue of endogeneity. Indeed, some of the explanatory variables identified in Section 2.2 (namely, openness, investment, and government balance) could potentially be endogenous, and ignoring this potential endogeneity may bias the results. Earlier work in the quantile regression literature has examined situations where the explanatory variables were potentially endogenous. For example, Amemiya (1982), Powell (1983), and Chen and Portnoy (1996) propose two-stage quantile estimators. Other approaches rely on IV and GMM quantile estimators, ${ }^{13}$ and control functions. ${ }^{14}$

To address the issue of endogeneity, we apply a two-stage quantile approach, where a quantile regression is implemented in both the first-stage estimation of the explanatory variables that are potentially endogenous (namely, openness, investment, and government balance) using the least absolute deviation, and in the second stage for the initial equation after plugging in the fitted values of the variables using first stage estimates. For our special variable of interest, openness, we get the required fitted values from a gravity model which we run separately. ${ }^{15}$ For the period of our analysis (1980-2006), we follow Frankel and Romer (1999) and regress bilateral trade on a vector consisting of various gravity variables: distance, land border, membership of regional trade agreement, and dummy variables indicating bilateral free trade agreements, historical ties, sharing of a common currency. ${ }^{16}$ Specifically, we estimate:

$$
\log \left(T_{i j t}\right)=a_{0}+\sum b_{k}^{\prime} \mathbf{W}_{i j t}+u_{i j t}
$$

where $T_{i j t}$ stands for the value of bilateral trade between countries $i$ and $j$ at time $t, \mathbf{W}_{i j t}$ is a vector of $k$ gravity variables and $u_{i j t}$ is an error term. Appendix $\mathrm{C}$ presents the results of the gravity regressions. Following the literature, we consider several estimators (pooled OLS, pooled OLS with country effects à la Anderson and van Wincoop (2003), panel country-pair fixed effects, and Hausman-Taylor ${ }^{17}$ ), to examine the robustness of the results. Estimated coefficients are in line with

\footnotetext{
${ }^{12}$ As discussed later excluding them from the list of robust variables does not make a difference to the quantile regression results.

${ }_{13}$ See, e.g., Abadie et al. (2002), Honoré and Hu (2004), Chernozhukov and Hansen (2005 and 2006), Chernohukov et al. (2007), and Sakata (2007).

${ }^{14}$ See Lee (2007).

${ }^{15}$ The other potentially endogenous variables, namely investment and government balance, are instrumented using their respective own lagged values in level and first-difference and by keeping only the lags that appeared to be significant in the first-stage regressions. We also consider the lagged values of the first-difference of the endogenous variable, as is current wisdom in the IV regressions.

${ }^{16}$ For a complete description of the model structure, see Tsangarides et al. (2009).

${ }^{17}$ See Hausman and Taylor (1981).
} 
results in the literature, and confirm the importance of the "gravity variables" (including GDP, distance, currency union and free-trade area participation) on bilateral trade. Both OLS and countryfixed effects are likely to be biased, so we focus our attention on the country-pair fixed effects and the Hausman-Taylor estimates. While the Hausman-Taylor estimates are able to identify the effect of time-invariant determinants (which drop out with the country-pair fixed effects) and can control for the endogeneity of certain determinants, the estimated coefficients are sometimes sensitive to the choice of instruments. In the end, we derive our fitted values for openness from the country-pair fixed effects. ${ }^{18}$

\section{Empirical results from quantile regressions}

The data set for the quantile regressions includes annual data for 1980-2006 from a sample of 75 developing countries: 27 from Africa, 11 from Asia and Pacific, 25 from Central and Latin America, 9 Middle East and Arab countries and 3 from Europe (see Appendix D). We choose to focus on this sample as there is enough variation within the developing countries to allow meaningful analysis and also to allow for comparisons with results in the literature. To summarize our empirical approach, the explanatory variables are those selected from the robustness analysis described in Section 2.2. ${ }^{19}$ Also, as described in Section 2.3, to control for the possible endogeneity of trade openness we retain the fitted values of bilateral trade obtained from the gravity estimates, while for the two other endogenous variables, we consider the first-stage quantile fitted values of government balance and investment.

\subsection{Estimation results}

Our growth equation is estimated as an error-correction model in order to allow for both short- and long-run impacts. The short-run effects are measured by the coefficients of the contemporaneous exogenous variables. The long-run impact is measured by the sum of the coefficients related to the contemporaneous and lagged variables divided by the coefficient of the real GDP. Table 1 reports the estimation results for the whole period, with the $25^{\text {th }}$ quantile of growth distribution representing countries with low-growth rates and the $75^{\text {th }}$ quantile those with high growth rates. First, the impact of openness on the per capita GDP growth rate in the two-stage quantile regressions is very different between low-growth and high-growth countries, as the estimated $25^{\text {th }}$ quantile coefficient is at least twice that of the $75^{\text {th }}$ quantile. In addition, openness is associated with a 3-8 percent increase in growth in the short run, while in the long-run growth varies less than proportionally in the highgrowth countries (0.75), but more than proportionally in the low-growth countries (1.6). In other words, in the short run, a $1 \%$ increase in openness leads to a $0.03 \%$ increase in the real GDP in the high-growth countries, and this effect is more than doubled in the low-growth countries (the elasticity being equal to $0.08 \%$ ).

\footnotetext{
${ }^{18}$ The predicted values from country-pair fixed effects and Hausman-Taylor estimates were very highly correlated (0.95-0.98), so the choice between the two estimators has virtually no impact on the quantile regression results.

${ }^{19}$ Strictly speaking, our quantile regressions also include the first-lagged values of our dependent variable, as well as those of the explanatory variables. While we may reasonably think that if a variable is found to be robust it may also be the case for the corresponding lagged variable, it would be interesting to implement the BMA analysis by including these lagged variables to rigorously check this assumption.
} 
A similar conclusion holds for the long-run impact where the elasticities fall in between 0.75 (highgrowth countries) and 1.6 (low-growth countries). These results suggest that the effect of openness is stronger for low-growth countries, both in the short and long run. Furthermore, comparing the twostage least-sum of absolute deviations (LAD) regression ( $50^{\text {th }}$ quantile) with GMM, it seems that the latter over-estimates the influence of trade in the short run, but under-estimates its impact in the long run. The other coefficients tend to be fairly similar across quantiles, with the notable difference of the variables capturing economic policies, namely inflation and government balance. Inflation is not significant for high-growth countries, while it significantly affects growth in low-growth countries. Like trade, the effect of fiscal policy is roughly doubled when we compare the high- and low-growth countries. This would mean that the trade-growth nexus is stronger in those countries where the economic policies also drive the economic growth. Trade per se is not a factor of growth, but it is complementary to the effects played by the other determinants.

\section{[Insert Table 1 here]}

Figure 1 reports the impact of trade at different quantiles, showing graphically how the impact of openness falls in size as we move to higher quantiles, with the coefficient dropping by about 60 percent until the $40^{\text {th }}$ percentile and falling less slowly there after as growth increases. Interestingly, we see that the decline in the impact of openness on growth is steeper for the lowest quantiles and less strong for the highest ones. This would mean that the impact of trade on growth is stronger in the very poor countries, suggesting that the benefits from openness are the strongest for countries that have the smallest growth rates.

\section{[Insert Figure 1 here]}

Next, we repeat the analysis of quantile regressions on two subperiods, namely 1980-1995 and 19962006. We break the sample period in this fashion to examine changes in the trade policy and liberalization during this period. In particular, the first subperiod of 1980-1995 was characterized by policies of trade and liberalization in many developing countries under structural adjustment programs supported by international financial institutions and the so-called "Washington consensus". However, up until the first half of the 1990s, these policies led to only short-lived recoveries in the Latin American countries and a few take-offs in Africa. During the second subperiod of the midnineties onwards there was a shift in the approach: trade policies were complemented by reforms putting a stronger focus on other macroeconomic and social policies including productivity-boosting reforms, spending on social programs, improving the investment climate, and the strengthening of institutions.

The results reported in Tables 2 and 3 show that the conclusions obtained for the whole period (19802006) in Table 1 are mainly driven by those of the second subperiod 1996-2006 (Table 3). For the subperiod 1980-1995, we find little evidence of any statistically significant correlation between trade openness and growth (Table 2). These results are in line with the stylized facts and empirical studies showing that trade openness based on first generation market-oriented policies have not lead to any economic boom in the developing countries (see Rodrik (1998), Easterly (2001), and World Bank (2005)).

[Insert Tables 2 and 3 here]

Overall, our finding that openness affects low-growth countries more than high-growth ones challenges the conclusions of most of the earlier cross-section and time-series studies that reveal 
either very little evidence of any statistical impact of trade on growth in the recent decades, or in some cases, a negative influence. ${ }^{20}$ We believe there are two (possibly reinforcing) reasons for this difference, the heterogeneous effect across quantiles and the focus of the analysis. As already discussed, quantile regressions reveal relationships that may otherwise be masked in the case where parameter heterogeneity is ignored, as typically done in earlier literature. In addition, most of the earlier studies focus on trade liberalization and its effect on developing countries, essentially testing the validity of the "Washington consensus". Failure to find a statistical link between liberalization and growth may reflect the results in Table 2, and the (now) rather well-established fact that trade policies have not played a significant role in growth performance of many developing countries in Africa, Latin America and even Asia (see Stiglitz (2005)). ${ }^{21}$

From an economic viewpoint, the differences in the trade impact on growth for low-growth and highgrowth countries may be explained by different internal preconditions, mainly relating to the domestic factors of economic growth such as productive infrastructure, human capital, investment and factor productivity. For instance, considering investment, Greenaway (1998) shows that countries which have increased investment following liberalization benefited from trade liberalization, while the liberalization impact on growth is negative for countries characterized by an investment slump. Similarly, Wacziarg and Welch (2003) report higher growth effects of liberalization for countries which experienced lower levels of trade taxes, higher levels of human capital, and higher import levels. Another important factor that may be seen as a key determinant of the heterogeneity of the trade-growth relationship has been highlighted by Foster (2008) and relates to the private sector's response to trade reforms. This point has to be linked to crises since reforms are frequently undertaken during periods of crisis, a fact that may weaken the positive effects of liberalization on growth. Finally, other factors that may be at play for explaining this heterogeneity have been investigated by Rodrik and Rodriguez (1999) and relate to the country's size, the level of development and comparative advantages. In summary, while various factors may explain our finding of a different trade-growth nexus for low- and high-growth countries, our results are in line with those of Foster (2008) suggesting that countries which benefited most from trade liberalization are those with lower per capita growth rates.

\subsection{Effect of a trade shock on growth}

To study the consequences of the heterogeneous response of growth to trade openness, we examine how the growth distribution changes when all countries in the sample are hit by the same trade shock. Such shocks affecting trade are exogenous, common to all countries, and can be either positive or negative. They can be of various types including changes in the prices of goods, suppression of trade barriers, and a drop in foreign demand caused by a world recession. We first compute the conditional probability density function for the growth rate of per capita GDP, using the estimated coefficients of (1) for different quantiles from the $10^{\text {th }}$ up to the $90^{\text {th }}$. Then, the obtained distribution is "shocked" by one standard error of the trade openness variable (the fitted variable from our gravity model).

Figures 2 and 3 show the growth conditional distribution corresponding to a situation with no shock on trade (solid lines) and the corresponding conditional distributions when the economies are "perturbed" with an exogenous shock to openness (darker lines), first for a positive shock and then a

\footnotetext{
${ }^{20}$ See Rodrik and Rodriguez (1999), UNDP (2003), and Wacziarg and Welch (2003).

21 Another reason may be that the liberalization variable (usually an indicator variable) cannot identify the differences in the extent of trade liberalization within countries.
} 
negative shock. The analysis reveals that a negative openness shock is associated with a more pronounced dispersion of the growth distribution and a reduction in the mean as the conditional distribution moves to the left. This suggests that countries in the lower tail are affected more by negative trade shocks, and their relative position in the income distribution widens resulting in a divergence effect. In contrast, a positive shock induces an increase in the mean and a reduction in the dispersion of the distribution, as the conditional distribution becomes leptokurtic. This suggests a catching-up effect between low- and high-growth countries and as a consequence, low-growth countries get closer to high-growth countries, suggesting convergence. Our results show that an exposure to a common trade shock affects growth in a heterogeneous manner. This has implications in the context of the current international crisis. A negative shock coming from the (already observed) drop in demand from developed countries may penalize low-growth countries more than the highgrowth ones.

\section{Robustness and sensitivity tests}

This section discusses the results of a number of robustness and sensitivity tests including tests for varying effects, omitted variables, and interaction effects. First, although our estimated short-run and long-run impact of trade openness on growth suggests varying effects across quantiles (see Figure 1), we formally test whether the coefficients estimated for the various quantiles are statistically different. Table 4 reports the results of the Wald tests for the whole period 1980-2006. ${ }^{22}$ The quantiles in rows are those against which the null assumption of equal slopes is tested, while the quantiles in columns refer to those that are estimated. The lower and upper triangular matrices contain the $p$-values of the test of slope equality for the short-run impact and the long-run impact, respectively. Statistically significant differences (lower $p$-values) suggest heterogeneity. ${ }^{23}$ Indeed, the reported results confirm that the quantile regressions estimate different impacts of openness on growth away from the middle portion of the sample. However, the heterogeneity is stronger for the long-run coefficients, since low $p$-values are found only for couples of extremely low and high quantiles.

[Insert Table 4 here]

Second, we conduct tests of omitted variables on two policy variables (government balance as share of GDP and inflation), the investment share, and terms of trade. Table 5 reports the constrained regressions and the $p$-values corresponding to the tests for the whole period 1980-2006. The omission of a variable is rejected for low $p$-values. We see that all the series-with the exception of the terms of trade for the $75^{\text {th }}$ quantile regression-are relevant explanatory variables in the regressions, and excluding them may bias the results. In particular, comparing the constrained regressions with those in Table 1, we see that the former often lead to an underestimation of the long-run effect of growth on trade openness for the low-growth countries (but have no effect for the high-growth countries).

[Insert Table 5 here]

Finally, we examine whether interacting trade openness with the control variables affects the results reported in Table $1 .^{24}$ The interactions capture the indirect effects of trade on growth through the

${ }^{22}$ Similar results are available for the subperiods upon request.

${ }^{23}$ The equality of slopes is rejected when the $p$-values are lower than $1 \%, 5 \%$ or $10 \%$.

${ }^{24}$ These results need to be interpreted with caution as the interaction variables have not been tested in the BMA, and hence, even when interactions are found relevant they may not be robust in the BMA sense. On this

(continued...) 
channels of investment, macroeconomic policies, and terms of trade. The investment channel may account for effects including productive resource availability or an indirect way of taking into account competitiveness. Estimates in Tables $6 \mathrm{a}$ and $6 \mathrm{~b}$ suggest that the trade coefficients in both the short and long run increase significantly when the indirect effect of trade on growth, via the investment share, is considered in the regression (Column (1)). For the high-growth countries, the impact of trade on growth is more than tripled and the magnitude of the coefficients increases slightly in the case of the low-income countries. With this new variable, we still find a stronger effect for the lowest quantiles. In Columns (2) and (3), we report the results corresponding to the interaction of trade and policy variables. High fiscal deficits and/or loose monetary policy yielding high inflation can hinder conditions conducive to trade by failing to attract capital required for production and export, and decreasing competitiveness. Our estimates in Tables $6 \mathrm{a}$ and $6 \mathrm{~b}$ show that the interacted effects of policy variables do affect the trade-growth nexus in the long run, as there is a significant negative effect of inflation in the low-growth countries and the overall long-run coefficient decreasing from 1.6 to 1 . Tables $6 \mathrm{a}$ and $6 \mathrm{~b}$ also report tests of omitted variables for the crossed terms. The results, for Columns (2) and (3), suggest that the indirect effect of trade through the inflation rate does matter in the low-growth countries, while government balance is the key policy channel in the high-growth economies. Finally, interacting trade with the terms of trade does not alter significantly the order of magnitude of the trade coefficients.

[Insert Tables 6a and 6b here]

\section{Conclusion}

The "heterogeneity" hypothesis has recently re-opened the debate in the literature investigating the trade-growth nexus. In this context, the empirical literature follows two strands. One is related to the question of omitted conditional variables in the classical regressions linking trade to growth. Another focuses on the application of more appropriate econometric tools to investigate the possibility of heterogeneous responses. In this paper, we attempt to control for both of these concerns, by applying quantile regression analysis, while controlling for identified robust growth determinants.

This paper shows that the response of growth performance to trade openness varies among the developing countries, thus providing empirical evidence of parameter heterogeneity. These results are in contrast to some earlier literature relying on mean-based approaches which mask the real effect and may sometimes lead to contradictory conclusions. Our findings suggest that, after conditioning on the robust growth determinants, openness has a higher impact on growth among low-growth countries relative to high-growth countries, with significantly larger short-run and long-run effects. We also show that trade openness shocks have an impact on the dispersion of international distribution of growth. We identify significant changes in the conditional growth distribution as a response to openness shocks, with positive shocks resulting in improvements in the distribution (higher mean income and smaller dispersion) and convergence effects, and negative shocks resulting in lower growth and wider dispersion around the mean. In terms of policy implications, our findings suggest that, on the one hand, low-growth countries could benefit the most from increasing trade openness, which would also help their convergence to the highest growth economies in the long run. On the other hand, increased trade dependency may raise vulnerability in situations of decreasing trade. As a

particular point, Crespo-Cuaresma and Doppelhofer (2007) introduce a Bayesian Averaging of Thresholds approach for assessing the impact of robust threshold effects in cross-country growth equations. 
result, in this case, countries that stand to gain the most from increased trade in the long run are also in danger of being hurt the most in the short run. 


\section{References}

Abadie, A., J. Angrist, and G. Imbens, 2002, "Instrumental Variables Estimation of the Effect of Subsidized Training on the Quantiles of Trainee Earnings," Econometrica, Vol. 70 (no. 1), pp. 91-117.

Amemiya, T., 1982, "2 Stage Least Absolute Deviations Estimators," Econometrica, Vol. 50 (no. 13), pp. 689-711.

Anderson, J., and E. van Wincoop (2003) "Gravity with Gravitas: A Solution to the Border Puzzle," American Economic Review, Vol. 93 (no. 1), pp. 170-192.

Baltagi, B., G. Bresson, and A. Pirotte, 2003, "Fixed Effects, Random Effects or Hausman-Taylor? A Pretest Estimator," Economics Letters, Vol. 79 (no. 3), pp. 361-369.

Barreto, P.A., and A. Hughes, 2004, "Under performers and Over Achievers: A Quantile regression Analysis of Growth," Economic Record, Vol. 80 (no. 248), pp. 17-35.

Barro, R.J., and J-W. Lee, 2000, "International Data on Educational Attainment. Updates and Implications," NBER Working Paper 7911, Cambridge, MA.

Barro, R.J., and X. Sala-1́-Martin, 1997, "Technological Diffusion, Convergence and Growth," Journal of Economic Growth, Vol. 2 (no. 1), pp. 1-26.

Billmeier, A., and T. Nannicini, 2007, "Trade Openness and Growth: Pursuing Empirical Glasnost," IMF Working Paper 07/156 (Washington: International Monetary Fund).

Brock, W., and S. Durlauf, 2001, "Growth Empirics and Reality," World Bank Economic Review, Vol. 15 (no. 2), pp. 229-272.

Brock, W., S. Durlauf, and K. West, 2003, "Policy Evaluation in Uncertain Economic Environments," Brookings Papers on Economic Activity (no. 1), pp. 235-332.

Buchinsky, M., 1998, "Recent Advances in Quantile Regression Methods: A Practical Guideline for Empirical Research," Journal of Human Resources, Vol. 33 (no. 1), pp. 88-126.

Calderón, C. and L. Servén, 2004, “Trend in Infrastructure in Latin America 1980-2001," Policy Research Working Paper Series 4712, World Bank.

Calderón, C. and L. Servén, 2008, "Infrastructure and Economic Development in Sub-Saharan Africa,” Policy Research Working Paper Series 3401, World Bank.

Chang, R., L. Kaltani, and N.V. Loayza, 2009, "Openness Can Be Good for Growth: The Role of Policy Complementarities,” Journal of Development Economics, Vol. 90 (no. 1), pp. 33-49.

Chay, K., 1995, "Evaluating the Impact of the 1964 Civil Rights Act on the Economic Status of Black Men Using Censored Longitudinal Earnings Data”, mimeograph, Princeton University. 
Chen, L..A., and D. Portnoy, 1996, "Two-Stage Regression Quantiles and Two-Stage Trimmed Least Squares Estimators for Structural Equations Models," Communications in Statistics - Theory and Methods, Vol. 25 (no. 5), pp. 1005-1032.

Chernozhukov, V., and C. Hansen, 2005, "An IV Model of Quantile Treatment Effects," Econometrica, Vol. 73 (no. 1), pp. 245-261.

Chernozhukov, V., and C. Hansen, 2006, "Instrumental Quantile Regression Inference for Structural and Treatment Effect Models," Journal of Econometrics, Vol. 132 (no. 2), pp. 491-525.

Chernozhukov, V., M. Jansson, and C. Hansen, 2007, "Inference Approaches for IV Quantile Regression," Economics Letters, Vol. 95 (no. 2) pp. 272-277.

Crespo-Cuaresma, J. and G. Doppelhofer (2007), "Nonlinearities in Cross-country Growth Regressions: A Bayesian Averaging of Thresholds (BAT) Approach," Journal of Macroeconomics, Vol. 29 (no. 3), pp. 541-554.

Crespo-Cuaresma, J., N. Foster and R. Stehrer, 2009, “The Determinants of Regional Economic Growth by Quantile," Working Papers 54, The Vienna Institute for International Economic Studies.

Cunningham, B. M., 2003, "The Distributional Heterogeneity of Growth Effects: Some Evidence," Manchester School, Vol. 71 (no. 4), pp. 417-447.

Devarajan, S., and D. Rodrik, 1989, "Trade Liberalization in Developing countries: Do Imperfect Competition and Scale Economies Matter?", American Economic Review, Vol. 79 (no. 2), pp. 283-287.

D’Orey, V., and R. Koenker, 1987, “Algorithm AS 229: Computing Regression Quantiles,” Applied Statistics, Vol. 36 (no. 3), pp. 383-393.

Dollar, D., and A. Kraay, 2003, "Institutions, Trade and Growth," Journal of Monetary Economics, Vol. 50 (no. 1), pp. 133-162.

Durlauf, S. and P. Johnson, 1995, "Multiple Regimes and Cross-country Growth Behavior," Journal of Applied Econometrics, Vol. 10 (no. 4), pp. 365-384.

Easterly, W., 2001, “The Lost Decades: Developing Countries' Stagnation in Spite of Policy Reforms 1980-1998," Journal of Economic Growth, Vol. 6 (no. 2), pp.135-157.

Easterly, W. and M. Sewadeh, 2001, "Global Development Network Growth Database," World Bank, Available at http://www.worldbank.org/research/growth/GDNdata.htm.

Eaton, J., and S. Kortum, 1999, "International Technology Diffusion: Theory and Measurement," International Economic Review, Vol. 40 (no. 3), pp. 537-570.

Fernàndez C., E. Ley, and M. Steel, 2001a, "Model Uncertainty in Cross-Country Growth Regressions," Journal of Applied Econometrics, Vol. 16 (no. 5), pp. 563-576. 
Fernàndez C., E. Ley, and M. Steel, 2001b, "Benchmark Priors for Bayesian Model Averaging," Journal of Econometrics, Vol. 100 (no. 2), pp. 381-427.

Foster, N., 2008, “The Impact of Trade Liberalisation on Economic Growth,” Kyklos, Vol. 61 (no. 4), pp. 543-567.

Frankel, J., and D. Romer, 1999, “Does trade cause growth?”, American Economic Review, Vol. 89 (no. 3), pp. 379-399.

Gallup, J., A. Mellinger and A. Sachs, 1999, “Geography and Economic Development," International Regional Science Review, Vol. 22 (no. 2), pp. 179-232.

Greenaway, D., 1998, "Does Trade Liberalisation Promote Economic Development?," Scottish Journal of Political Economy, Vol. 45 (no. 5), pp. 491-511.

Grossman, G.M., and E. Helpman, 1991a, Innovation and Growth in the Global Economy (Cambridge, Massachusetts: MIT Press).

— 1991b, "Trade, Knowledge Spillovers and Growth," European Economic Review, Vol. 35 (no. 2-3), pp. 517-526.

Hansen, B.E., 2000, "Sample, Splitting and Threshold Estimation," Econometrica, Vol. 68 (no. 3), pp. 575-603.

Hausman, J.A. and W.E. Taylor (1981), "Panel data and unobservable individual effects," Econometrica, Vol. 49 (no. 6), pp. 1377-1398.

Hendry, D.F. and H.M. Krolzig, 2004, "We Ran One Regression," Oxford Bulletin of Economics and Statistics, Vol. 66 (no. 5), pp. 799-810.

Heston, A., Summers, R. and B. Aten, 2002, Penn World Table Version 6.1., Center for International Comparisons of Production, Income and Prices at the University of Pennsylvania, October 2002. Available at http://pwt.econ.upenn.edu/php_site/pwt61_form.php.

Honoré, B. E., and L. Hu, 2004, "On the Performance of Some Robust Instrumental Variables Estimators," Journal of Business and Economics Statistics, Vol. 22 (no. 1), pp. 30-39.

International Monetary Fund, 2008a, International Financial Statistics (IFS), Washington, DC. Available at http://www.imfstatistics.org/imf/about.asp.

International Monetary Fund, 2008b, World Economic Outlook, Washington, DC. Available at http://www.imf.org/external/ns/cs.aspx?id=28.

Koenker, R., 1994, "Confidence Intervals for Regression Quantiles" in Asymptotic Statistics, ed by P. Mandl and M. Huskova (New York: Springer-Verlag).

— , 2004, "Quantile Regression for Longitudinal Data," Journal of Multivariate Analysis, Vol. 91 (no. 1), pp. 74-89. 
—, 2005, Quantile Regression, Econometric Society Monograph Series, Cambridge University Press.

—

— , and G., Bassett, 1982, "Tests of Linear Hypotheses and $l 1$ Estimation," Econometrica, Vol. 50 (no. 6), pp. 1577-1584.

—, and K.F., Hallock, 2001, "Quantile Regression," Journal of Economic Perspectives, Vol. 15 (no. 4), pp. 143-156.

Krugman, P. R., 1990, Rethinking International Trade, Cambridge, Massachusetts: MIT Press.

Leamer, E., 1978, Specification Searches: Ad Hoc Inference with Non-experimental Data (New York: Wiley).

Lee, S., 2007, "Endogeneity in Quantile Regression Models: A Control Function Approach," Journal of Econometrics, Vol. 141 (no. 2), pp. 1131-1158.

Levine, R. and D. Renelt, 1992, "A Sensitivity Analysis of Cross-country Growth regressions," American Economic Review, Vol. 82 (no. 4), pp. 942-963.

Marshall, M. G., and K. Jaggers, 2008, Polity IV Project: Political Regime Characteristics and Transitions, 1800-2008, Center for Systemic Peace, George Mason University. Available at http://www.systemicpeace.org/polity/polity4.htm.

Masanjala, W. and C. Papageorgiou, 2008, "A Rough and Lonely Road to Prosperity: A ReExamination of Sources of Growth in Africa Using Bayesian Model Averaging," Journal of Applied Econometrics, Vol. 23 (no. 5), pp. 671-682.

Mirestean A., and C. Tsangarides, 2009, "Growth Determinants Revisited," IMF Working Paper 09/268 (Washington: International Monetary Fund).

Mello, M., and R. Perrelli, 2003, "Growth Equations: A Quantile Regression Exploration," The Quarterly Review of Economics and Finance, Vol. 43 (no. 4), pp. 643-667.

North, D., 1990, Institutions, Institutional Change and Economic Performance, Cambridge University Press.

Osborne, E., 2006, "The Sources of Growth at Different Levels of Development," Contemporary Economic Policy, Vol. 24 (no. 4), pp. 536-547.

Papageorgiou, C., 2002, "Trade as a Threshold Variable for Multiple Regimes," Economics Letters, Vol. 77 (no. 1), pp. 85-91.

Powell, J.L., 1983, "The Asymptotic Normality of Two-stage Least Absolute Deviations Estimators," Econometrica, Vol. 51 (no. 5), pp. 1569-1576. 
Raftery, A. E., 1995, "Bayesian Model Selection in Social Research," Sociological Methodology, Vol. 25, pp. 111-163.

Raftery, A.E., D. Madigan, and J. A. Hoeting, 1997, "Bayesian Model Averaging for Linear Regression Models,” Journal of the American Statistical Association, Vol. 92 (no. 437), pp. 179-191.

Rassekh, F., 2004, "The Interplay of International Trade, Economic Growth and Income Convergence: A Brief Intellectual History of Recent Developments," Journal of International Trade and Economic Development, Vol. 13 (no. 4), pp. 203-228.

Rivera-Batiz, L.A., and P.M. Romer, 1991, "Economic Integration and Endogenous Growth," Quarterly Journal of Economics, Vol.106 (no. 2), pp. 531-555.

Rodrik, D., 1998, “Trade Policy and Economic Performance in Sub-Saharan Africa," NBER Working Paper 6562, Cambridge, MA.

Rodrik, D., and F. Rodriguez, 1999, "Trade Policy and Economic Growth: A Skeptic's Guide to the Cross National Evidence,” NBER Working Paper 7081, Cambridge, MA.

Sakata, S., 2007, "Instrumental Variable Estimation Based on Conditional Median Restriction," Journal of Econometrics, Vol. 141 (no. 2), pp. 350-382.

Sala-1́-Martin, X., 1997, “I Just Ran Two Million Regressions,” American Economic Review, Vol. 87 (no. 2), pp. 178-183.

Sala-1́-Martin, X., Doppelhofer, G., R., and I. Miller, 2004, "Determinants of Long-Term Growth: A Bayesian Averaging of Classical Estimates (BACE) Approach," American Economic Review, Vol. 94 (no. 4), pp. 813-835.

Sambanis, N., 2000, "Partition as a Solution to Ethnic War: An Empirical Critique of the Theoretical Literature," World Politics, Vol. 52 (no. 4), pp. 437-483.

Stiglitz, J.E., 2005, "Development Policies in a World of Globalization," in Gallagher, K.P. (ed), Putting Development First: the Importance of Policy Space in the WTO and IFIs, ZED Books, London and New York.

Tsangarides, C., 2005, “Growth Empirics under Model Uncertainty. Is Africa Different?”, IMF Working Paper 05/18 (Washington: International Monetary Fund).

—, Ewenczyk, P., and M. Hulej, 2009, “Are Africa's Currency Unions Good for Trade?”, IMF Staff Papers, Vol. 56 (no. 4), pp. 876-918.

UNDP, 2003, A World of Development Experience, Annual Report, Available at http://www.undp.org/annualreports/2003/english/IAR03completeE.pdf.

Wacziarg, R., and K. H. Welch, 2003, "Trade Liberalization and Growth: New Evidence”, NBER Working Paper 10152, National Bureau of Economic Research, Cambridge, MA. 
World Bank, 2005, Economic Growth in the Nineties: Learning From a Decade of Reforms, Washington, DC.

World Bank, 2008, World Development Indicators, Washington, DC. Available at http://databank.worldbank.org/ddp/home.do.

Young, A., 1991, "Learning by Doing and the Dynamic effects of International Trade," Quarterly Journal of Economics, Vol. 106 (no. 2), pp. 369-405.

Zou, H., 2006, "The Adaptive LASSO and its Oracle Properties," Journal of the American Economic Association, Vol. 101 (no. 476), pp. 1418-1429. 
Table 1. GMM and Two-Stage Quantile Regressions 1980-2006 Dependent variable: per-capita real GDP growth

\begin{tabular}{|c|c|c|c|c|}
\hline & \multirow[t]{2}{*}{ GMM } & \multicolumn{3}{|c|}{ Two-stage quantile regressions } \\
\hline & & 0.5 & 0.25 & 0.75 \\
\hline & $(1)$ & (2) & (3) & $(4)$ \\
\hline \multirow[t]{2}{*}{ Real GDP(-1) } & -0.21 & $-0.03 * * *$ & $-0.05 * * *$ & $-0.04 * * *$ \\
\hline & - & $(-4.20)$ & $(-6.03)$ & $(-3.95)$ \\
\hline \multirow[t]{2}{*}{ Investment share } & $0.06 * * *$ & $0.05 * * *$ & $0.05 * *$ & $0.06 * * *$ \\
\hline & $(4.71)$ & $(4.64)$ & $(2.47)$ & $(3.67)$ \\
\hline \multirow[t]{2}{*}{ Government balance } & -0.03 & $0.23 * * *$ & $0.28 * *$ & 0.15 \\
\hline & $(-0.79)$ & $(2.82)$ & $(2.50)$ & $(1.18)$ \\
\hline \multirow[t]{2}{*}{ Population growth } & -0.006 & $-0.04 * * *$ & $-0.04 * * *$ & $-0.04 * * *$ \\
\hline & $(-0.50)$ & $(-2.95)$ & $(-9.71)$ & $(-3.70)$ \\
\hline \multirow[t]{2}{*}{ Terms of trade growth } & -0.008 & 0.005 & 0.01 & 0.002 \\
\hline & $(-0.84)$ & $(1.56)$ & $(1.30)$ & $(0.96)$ \\
\hline \multirow[t]{2}{*}{ Inflation } & 0.005 & $-0.01 * *$ & $-0.02 * * *$ & -0.02 \\
\hline & $(0.78)$ & $(-2.38)$ & $(-4.02)$ & $(-1.59)$ \\
\hline \multicolumn{5}{|l|}{ Trade } \\
\hline \multirow[t]{2}{*}{ Openness } & $0.09 * * *$ & - & - & - \\
\hline & $(3.64)$ & & & \\
\hline \multirow[t]{2}{*}{ Gravity } & - & $0.04 * * *$ & $0.08 * * *$ & $0.03 * *$ \\
\hline & & $(2.90)$ & $(5.02)$ & $(1.96)$ \\
\hline \multirow[t]{2}{*}{ Investment share(-1) } & 0.01 & -0.01 & -0.005 & -0.02 \\
\hline & $(0.98)$ & $(-0.80)$ & $(-0.25)$ & $(-1.07)$ \\
\hline \multirow[t]{2}{*}{ Government balance(-1) } & $0.28 * * *$ & -0.04 & -0.001 & -0.01 \\
\hline & $(12.83)$ & $(-0.38)$ & $(-0.01)$ & $(-0.15)$ \\
\hline \multirow[t]{2}{*}{ Population growth(-1) } & $-0.06 * * *$ & 0.01 & 0.003 & $0.014 * *$ \\
\hline & $(-4.20)$ & -0.91 & $(0.43)$ & $(2.14)$ \\
\hline \multirow[t]{2}{*}{ Terms of trade growth(-1) } & $-0.02 * *$ & $0.009 * * *$ & $0.02 * * *$ & 0.014 \\
\hline & $(-2.22)$ & $(2.75)$ & $(5.69)$ & $(1.26)$ \\
\hline \multirow[t]{2}{*}{ Inflation(-1) } & $-0.02 * * *$ & 0.004 & $0.008 * *$ & 0.01 \\
\hline & $(-2.69)$ & $(0.99)$ & $(2.18)$ & $(0.99)$ \\
\hline \multicolumn{5}{|l|}{ Trade } \\
\hline \multirow[t]{2}{*}{ Openness(-1) } & -0.004 & - & - & - \\
\hline & $(-0.25)$ & & & \\
\hline \multirow[t]{2}{*}{ Gravity(-1) } & - & -0.01 & -0.03 & -0.004 \\
\hline & & $(-0.93)$ & $(-1.55)$ & $(-0.29)$ \\
\hline $\begin{array}{rr}\text { Pseudo } \mathrm{R}^{2} \\
\end{array}$ & - & 0.23 & 0.26 & 0.25 \\
\hline \multicolumn{5}{|l|}{ Impact of trade on growth } \\
\hline Short run & 0.09 & 0.04 & 0.08 & 0.03 \\
\hline Long run & 0.43 & 1.33 & 1.6 & 0.75 \\
\hline
\end{tabular}

Notes:

1. GMM estimations in column (1), and two-stage quantile estimations in columns (2)-(4). All regressions include country dummies; $t$-statistics in brackets. $* * *$ significant at $1 \%, * *$ significant at $5 \%, *$ significant at $10 \%$.

2. The sparsity function is computed using a kernel method (the results are robust to other methods such as bootstrap or Siddiqui).

3. The short-run impact is given by the openness coefficient; the long-run impact is given by the absolute value of the ratio of openness to the lagged value of per capita GDP growth rate.

4. Instruments used both for GMM and in the first-stage quantile regressions are lagged values of the endogenous and explanatory variables as well as lagged values of their first difference. 
Table 2. GMM and Two-Stage Quantile Regressions 1980-1995 Dependent variable: per-capita real GDP growth

\begin{tabular}{|c|c|c|c|c|}
\hline & \multirow[t]{2}{*}{ GMM } & \multicolumn{3}{|c|}{ Two-stage quantile regressions } \\
\hline & & 0.5 & 0.25 & 0.75 \\
\hline & (1) & (2) & (3) & (4) \\
\hline \multirow[t]{2}{*}{ Real GDP(-1) } & -0.21 & $-0.04 * *$ & -0.02 & $-0.06 * * *$ \\
\hline & - & $(-2.44)$ & $(-1.08)$ & $(-3.82)$ \\
\hline \multirow[t]{2}{*}{ Investment share } & $0.08 * * *$ & 0.04 & 0.04 & 0.04 \\
\hline & $(8.38)$ & $(1.33)$ & $(1.18)$ & $(1.01)$ \\
\hline \multirow[t]{2}{*}{ Government balance } & $-0.1 * * *$ & $0.48 * *$ & $0.53 * *$ & 0.28 \\
\hline & $(-3.99)$ & $(2.20)$ & $(2.44)$ & $(0.91)$ \\
\hline \multirow[t]{2}{*}{ Population growth } & -0.001 & $-0.02 * *$ & $-0.02 *$ & -0.03 \\
\hline & $(-0.26)$ & $(-2.18)$ & $(-1.91)$ & $(-0.98)$ \\
\hline \multirow[t]{2}{*}{ Terms of trade growth } & -0.009 & $0.01 * *$ & $0.01 * *$ & 0.005 \\
\hline & $(-1.44)$ & $(2.14)$ & $(1.98)$ & $(0.26)$ \\
\hline \multirow[t]{2}{*}{ Inflation } & 0.005 & $-0.02 * *$ & $-0.02 * * *$ & _ 0.01 \\
\hline & $(1.21)$ & $(-2.18)$ & $(-4.06)$ & $(-1.22)$ \\
\hline \multicolumn{5}{|l|}{ Trade } \\
\hline Openness & $\begin{array}{l}0.10 \text { *** } \\
(7.58)\end{array}$ & - & - & - \\
\hline \multirow[t]{2}{*}{ Gravity } & - & 0.03 & $0.04 *$ & 0.03 \\
\hline & & $(1.32)$ & $(1.60)$ & $(1.16)$ \\
\hline \multirow[t]{2}{*}{ Investment share(-1) } & 0.01 & -0.04 & -0.04 & $-0.07 *$ \\
\hline & $(1.51)$ & $(-1.52)$ & $(-1.50)$ & $(-1.69)$ \\
\hline \multirow[t]{2}{*}{ Government balance(-1) } & $0.29 * * *$ & -0.146 & -0.03 & -0.06 \\
\hline & $(15.74)$ & $(-0.64)$ & $(-0.17)$ & $(-0.25)$ \\
\hline \multirow[t]{2}{*}{ Population growth(-1) } & $-0.06 * * *$ & $0.02 * *$ & 0.003 & 0.03 \\
\hline & $(-6.20)$ & $(2.34)$ & $(0.26)$ & $(1.44)$ \\
\hline \multirow[t]{2}{*}{ Terms of trade growth(-1) } & $-0.02 * *$ & $0.02 * * *$ & $0.02 * * *$ & 0.007 \\
\hline & $(-3.13)$ & $(2.99)$ & $(2.7)$ & $(0.26)$ \\
\hline \multirow[t]{2}{*}{ Inflation(-1) } & -0.009 & 0.003 & 0.0002 & -0.0002 \\
\hline & $(-1.41)$ & $(0.36)$ & $(0.05)$ & $(-0.01)$ \\
\hline \multicolumn{5}{|l|}{ Trade } \\
\hline Openness(-1) & $\begin{array}{c}-0.02 * \\
(-1.89)\end{array}$ & - & - & - \\
\hline \multirow[t]{2}{*}{ Gravity(-1) } & - & -0.003 & -0.006 & 0.01 \\
\hline & & $(-0.12)$ & $(-0.19)$ & $(0.35)$ \\
\hline $\begin{array}{rr}\text { Pseudo R } \\
\end{array}$ & - & 0.28 & 0.32 & 0.31 \\
\hline \multicolumn{5}{|l|}{ Impact of trade on growth } \\
\hline Short run & 0.10 & 0.0 & 0.0 & 0.0 \\
\hline Long run & 0.36 & 0.0 & 0.0 & 0.0 \\
\hline
\end{tabular}

Notes:

See notes for Table 1 . 
Table 3. GMM and Two-Stage Quantile Regressions 1996-2006 Dependent variable: per-capita real GDP growth

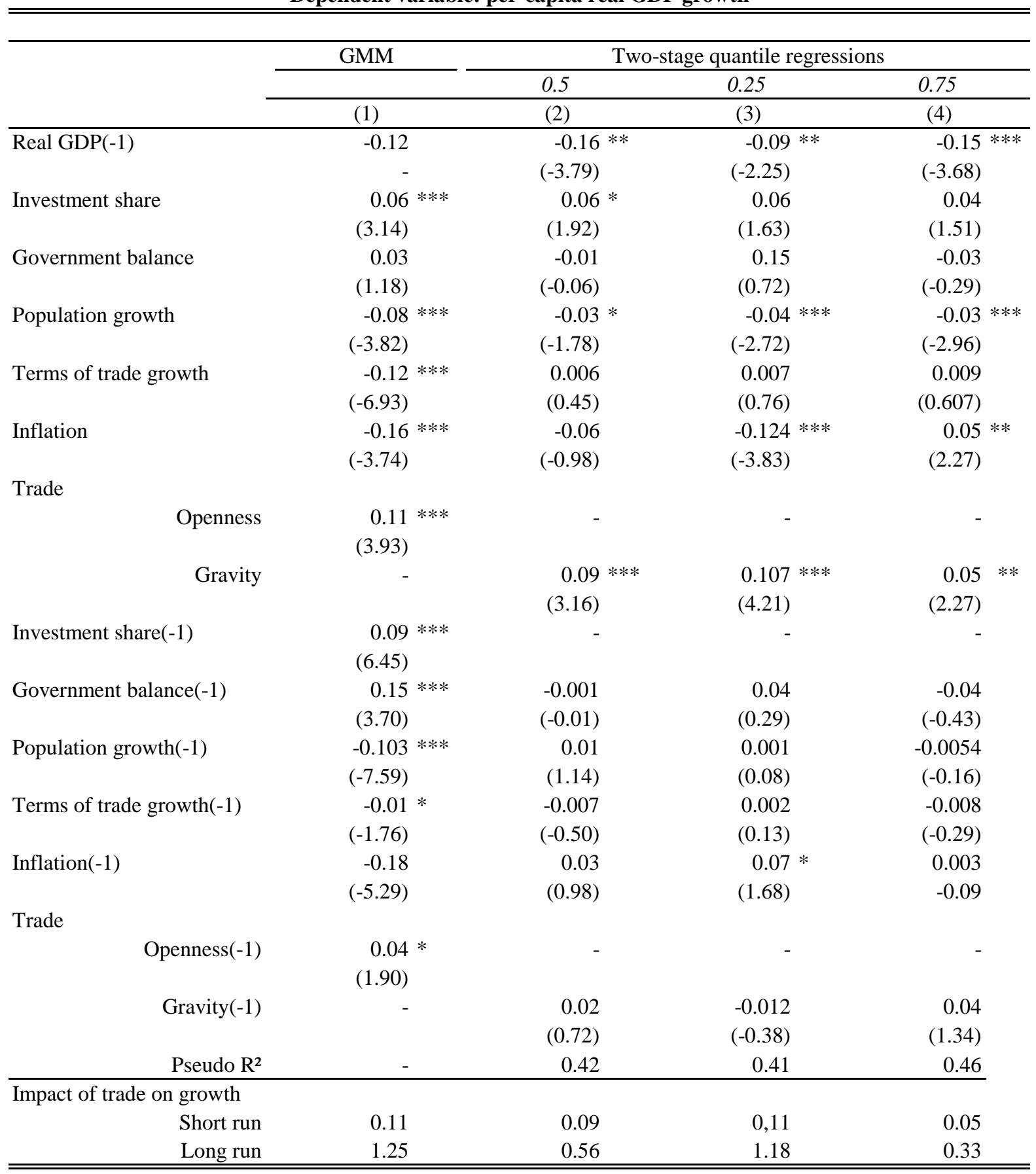

Notes:

See notes for Table 1 . 
Table 4. Tests for Varying Effects of Trade Openness on Growth across Quantiles ( $p$ values of the Wald test)

\begin{tabular}{|c|c|c|c|c|c|c|c|}
\hline & 0.2 & 0.25 & 0.4 & 0.5 & 0.6 & 0.75 & 0.8 \\
\hline 0.2 & - & 0.57 & 0.38 & 0.43 & 0.24 & 0.01 & 0.03 \\
\hline 0.25 & 0.68 & - & 0.72 & 0.72 & 0.45 & 0.05 & 0.06 \\
\hline 0.4 & 0.03 & 0.13 & - & 0.87 & 0.57 & 0.09 & 0.10 \\
\hline 0.5 & 0.02 & 0.09 & 0.66 & - & 0.57 & 0.09 & 0.10 \\
\hline 0.6 & 0.00 & 0.02 & 0.31 & 0.70 & - & 0.38 & 0.46 \\
\hline 0.75 & 0.00 & 0.01 & 0.16 & 0.44 & 0.89 & - & 0.96 \\
\hline 0.8 & 0.00 & 0.01 & 0.17 & 0.45 & 0.89 & 0.62 & - \\
\hline
\end{tabular}

Notes:

Lower triangular matrix: short-run effects. Upper triangular matrix: long-run effects.

The null hypothesis of slope equality for the openness variables across quantiles is rejected when the $p$-value lies below $1 \%, 5 \%$ or $10 \%$. 
Table 5. Constrained Regressions and Tests of Omitted Variables

Two-stage quantile regressions 1980-2006

Dependent variable: per-capita real GDP growth

\begin{tabular}{|c|c|c|c|c|c|c|}
\hline & & 0.25 & & & 0.75 & \\
\hline & (1) & (2) & (3) & (1) & (2) & (3) \\
\hline Real GDP(-1) & $\begin{array}{l}-0.06 \text { *** } \\
(-7.31)\end{array}$ & $\begin{array}{l}-0.06 \text { *** } \\
(-7.45)\end{array}$ & $\begin{array}{l}-0.03 \text { *** } \\
(-4.64)\end{array}$ & $\begin{array}{l}-0.05 \text { *** } \\
(-4.82)\end{array}$ & $\begin{array}{l}-0.05 \text { *** } \\
(-5.74)\end{array}$ & $\begin{array}{l}-0.02 \text { *** } \\
(-3.63)\end{array}$ \\
\hline Investment share & $\begin{array}{l}0.08 \text { *** } \\
(3.16)\end{array}$ & - & $\begin{array}{l}0.07 \text { *** } \\
(2.53)\end{array}$ & $\begin{array}{l}0.06 \text { *** } \\
(4.36)\end{array}$ & - & $\begin{array}{l}0.07 * * * \\
(4.92)\end{array}$ \\
\hline Government balance & - & $\begin{array}{l}0.32 \text { *** } \\
(2.51)\end{array}$ & $\begin{array}{l}0.36 \text { *** } \\
(2.65)\end{array}$ & - & $\begin{array}{r}0.09 \\
(1.11)\end{array}$ & $\begin{array}{l}0.27 * * \\
(2.12)\end{array}$ \\
\hline Population growth & $\begin{array}{l}-0.04 * * * \\
(-7.98)\end{array}$ & $\begin{array}{l}-0.05 * * * \\
(-2.06)\end{array}$ & $\begin{array}{l}-0.06 \text { *** } \\
(-6.12)\end{array}$ & $\begin{array}{l}-0.04 * * * \\
(-3.44)\end{array}$ & $\begin{array}{l}-0.04 \text { *** } \\
(-3.59)\end{array}$ & $\begin{array}{l}-0.06 * * * \\
(-4.97)\end{array}$ \\
\hline Terms of trade growth & $\begin{array}{c}0.01 * \\
(1.85)\end{array}$ & $\begin{array}{l}0.01 \text { ** } \\
(2.22)\end{array}$ & - & $\begin{array}{r}0.02 \\
(1.66)\end{array}$ & $\begin{array}{r}0.00 \\
(1.37)\end{array}$ & - \\
\hline Inflation & - & $-0.02 * * *$ & $\begin{array}{r}-0.03 \\
(-0.91)\end{array}$ & - & $\begin{array}{c}-0.01 * \\
(-1.82)\end{array}$ & $\begin{array}{r}-0.02 \\
(-0.89)\end{array}$ \\
\hline Openness from gravity & $\begin{array}{l}0.08 \text { *** } \\
(4.91)\end{array}$ & $(5.45)^{* * *}$ & $\begin{array}{l}0.07 \text { *** } \\
(4.53)\end{array}$ & $\begin{array}{l}0.04 \text { ** } \\
(2.40)\end{array}$ & $\begin{array}{l}0.04 \text { *** } \\
(2.84)\end{array}$ & $\begin{array}{l}0.02 * \\
(1.74)\end{array}$ \\
\hline Investment share(-1) & $\begin{array}{r}-0.01 \\
(-0.82)\end{array}$ & - & $\begin{array}{r}-0.01 \\
(-0.39)\end{array}$ & $\begin{array}{l}-0.02 * \\
(-1.75)\end{array}$ & - & $\begin{array}{l}-0.03 * * \\
(-2.49)\end{array}$ \\
\hline Government balance(-1) & - & $\begin{array}{r}0.00 \\
(0.00)\end{array}$ & $\begin{array}{r}-0.02 \\
(-0.13)\end{array}$ & - & $\begin{array}{r}0.06 \\
(0.82)\end{array}$ & $\begin{array}{r}-0.02 \\
(-0.22)\end{array}$ \\
\hline Population growth(-1) & 0.00 & $\begin{array}{r}0.01 \\
(0.28)\end{array}$ & $\begin{array}{r}-0.00 \\
(-0.51)\end{array}$ & $\begin{array}{r}0.01 \\
(0.44)\end{array}$ & $\begin{array}{r}0.01 \\
(0.90)\end{array}$ & $\begin{array}{r}-0.01 \\
(-0.79)\end{array}$ \\
\hline Terms of trade growth(-1) & $\begin{array}{r}0.01 \\
(0.64)\end{array}$ & $\begin{array}{l}0.02 \text { *** } \\
(5.13)\end{array}$ & - & $\begin{array}{r}0.02 \\
(1.66)\end{array}$ & $\begin{array}{r}0.01 \\
(1.08)\end{array}$ & - \\
\hline Inflation(-1) & - & $\begin{array}{l}0.01 \text { ** } \\
(2.17)\end{array}$ & $\begin{array}{r}0.01 \\
(1.06)\end{array}$ & - & $\begin{array}{r}0.01 \\
(0.63)\end{array}$ & $\begin{array}{r}0.01 \\
(0.80)\end{array}$ \\
\hline Openness from gravity(-1) & $\begin{array}{r}-0.01 \\
(0.01)\end{array}$ & $\begin{array}{l}-0.04 * \\
(1.76)\end{array}$ & $\begin{array}{l}-0.04 * * \\
(-2.39)\end{array}$ & $\begin{array}{r}-0.00 \\
(-0.17)\end{array}$ & $\begin{array}{r}-0.01 \\
(-0.56)\end{array}$ & $\begin{array}{r}-0.01 \\
(-0.99)\end{array}$ \\
\hline Pseudo $\mathrm{R}^{2}$ & 0.23 & 0.24 & 0.23 & 0.22 & 0.22 & 0.22 \\
\hline Impact of trade on growth & & & & & & \\
\hline Short run & 0.08 & 0.09 & 0.07 & 0.04 & 0.04 & 0.02 \\
\hline Long run & 1.33 & 0.83 & 0.00 & 0.80 & 0.80 & 1.00 \\
\hline Omitted ( $p$-value) & 0.00 & 0.00 & 0.00 & 0.01 & 0.00 & 0.11 \\
\hline
\end{tabular}

Notes:

1. $t$-statistics in brackets. $* * *$ significant at $1 \%, * *$ significant at $5 \%$, significant at $10 \%$.

2. The sparsity function is computed using a kernel method (the results are robust to other methods such as bootstrap and Siddiqui).

3. Instruments used in the first-stage quantile regressions are lagged values of the endogenous and explanatory variables as well as lagged values of their first difference.

4. The last line shows the $p$-value of the Wald tests for the omitted variables, respectively

Government balance and inflation (Column (1)), Investment share (Column (2)) and terms of trade (Column (3)). 
Table 6a. Two-Stage Quantile Regressions with Interaction Terms (25th Quantile) Dependent variable: per-capita real GDP growth (25th quantile)

\begin{tabular}{|c|c|c|c|c|}
\hline & $(1)$ & $(2)$ & (3) & $(4)$ \\
\hline Real GDP(-1) & $\begin{array}{l}-0.08 * * * \\
(-6.56)\end{array}$ & $\begin{array}{l}-0.06 * * * \\
(-5.73)\end{array}$ & $\begin{array}{l}-0.06 \text { *** } \\
(-6.51)\end{array}$ & $\begin{array}{l}-0.06 \text { *** } \\
(-6.05)\end{array}$ \\
\hline Investment share & $\begin{array}{l}0.06 \text { *** } \\
(2.88)\end{array}$ & $\begin{array}{l}0.07 * * \\
(2.43)\end{array}$ & $\begin{array}{l}0.07 \text { *** } \\
(2.90)\end{array}$ & $\begin{array}{l}0.06 \text { ** } \\
(2.43)\end{array}$ \\
\hline Government balance & $\begin{array}{l}0.28 * * \\
(2.29)\end{array}$ & $\begin{array}{l}0.31 * * * \\
(2.84)\end{array}$ & $\begin{array}{l}0.26 * * \\
(2.20)\end{array}$ & $\begin{array}{l}0.28 * * \\
(2.25)\end{array}$ \\
\hline Population growth & $\begin{array}{l}-0.05 * * * \\
(3.16)\end{array}$ & $\begin{array}{l}-0.05 * * * \\
(-5.60)\end{array}$ & $\begin{array}{l}-0.05 \text { *** } \\
(-8.47)\end{array}$ & $\begin{array}{l}-0.05 * * * \\
(-4.90)\end{array}$ \\
\hline Terms of trade growth & $\begin{array}{r}0.01 \\
(0.98)\end{array}$ & $\begin{array}{r}0.01 \\
(1.37)\end{array}$ & $\begin{array}{l}0.01 \text { *** } \\
(4.55)\end{array}$ & $\begin{array}{l}0.01 * * * \\
(4.36)\end{array}$ \\
\hline Inflation & $\begin{array}{l}-0.02 \text { *** } \\
(-3.24)\end{array}$ & $\begin{array}{l}-0.02 * * * \\
(-3.61)\end{array}$ & $\begin{array}{l}-0.02 \text { *** } \\
(-8.69)\end{array}$ & $\begin{array}{l}-0.02 * * * \\
(-3.50)\end{array}$ \\
\hline Trade (openness from gravity) & $\begin{array}{l}0.16 \text { *** } \\
(4.84)\end{array}$ & $\begin{array}{l}0.08 * * * \\
(4.91)\end{array}$ & $\begin{array}{l}0.08 \text { *** } \\
(6.89)\end{array}$ & $\begin{array}{l}0.08 \text { *** } \\
(5.36)\end{array}$ \\
\hline Trade $\mathrm{x}$ investment share $(-1)$ & $\begin{array}{l}0.05 * * \\
(2.77)\end{array}$ & - & - & - \\
\hline Trade x Gvt balance(-1) & - & $\begin{array}{r}0.04 \\
(0.23)\end{array}$ & - & - \\
\hline Trade $\mathrm{x}$ Inflation(-1) & - & - & $\begin{array}{l}-0.02 \text { *** } \\
(-3.13)\end{array}$ & - \\
\hline Trade $\times$ TOT growth(-1) & - & - & - & $\begin{array}{r}0.00 \\
(-0.01)\end{array}$ \\
\hline Investment share $(-1)$ & $\begin{array}{l}0.08 * * \\
(2.66)\end{array}$ & $\begin{array}{r}-0.01 \\
(-0.41)\end{array}$ & $\begin{array}{r}-0.01 \\
(-0.72)\end{array}$ & $\begin{array}{r}-0.01 \\
(-0.30)\end{array}$ \\
\hline Government balance(-1) & $\begin{array}{r}-0.19 \\
(-1.43)\end{array}$ & $\begin{array}{r}-0.03 \\
(-0.08)\end{array}$ & $\begin{array}{r}-0.05 \\
(-0.38)\end{array}$ & $\begin{array}{r}-0.04 \\
(-0.22)\end{array}$ \\
\hline Population growth(-1) & $\begin{array}{r}0.00 \\
(0.39)\end{array}$ & $\begin{array}{r}0.00 \\
(0.30)\end{array}$ & $\begin{array}{r}0.00 \\
(0.51)\end{array}$ & $\begin{array}{r}0.00 \\
(0.48)\end{array}$ \\
\hline Terms of trade growth(-1) & $\begin{array}{r}0.02 \\
(1.13)\end{array}$ & $\begin{array}{l}0.02 * * * \\
(5.03)\end{array}$ & $\begin{array}{l}0.02 * * * \\
(4.76)\end{array}$ & $\begin{array}{r}0.02 \\
(0.77)\end{array}$ \\
\hline Inflation(-1) & $\begin{array}{l}0.01 \text { *** } \\
(2.47)\end{array}$ & $\begin{array}{r}0.01 \\
(1.27)\end{array}$ & $\begin{array}{l}-0.03 * * \\
(-2.23)\end{array}$ & $\begin{array}{r}0.01 \\
(1.14)\end{array}$ \\
\hline Trade(-1) (Openness from gravity(-1)) & $\begin{array}{r}-0.00 \\
(-0.17)\end{array}$ & $\begin{array}{r}-0.03 \\
(-1.54)\end{array}$ & $\begin{array}{r}-0.03 \\
(-1.67)\end{array}$ & $\begin{array}{l}-0.03 * \\
(-1.76)\end{array}$ \\
\hline Trade(-1) $x$ investment share $(-2)$ & $\begin{array}{r}0.01 \\
-0.95\end{array}$ & - & - & - \\
\hline Trade(-1) x Gvt balance $(-2)$ & - & $\begin{array}{l}(-0.02) \\
(-0.22)\end{array}$ & - & - \\
\hline Trade(-1) x Inflation(-2) & - & - & $\begin{array}{r}0.0 \\
(-0.02)\end{array}$ & - \\
\hline Trade(-1) x TOT growth(-2) & - & - & - & $\begin{array}{r}-0.01 \\
(-3.73)\end{array}$ \\
\hline $\begin{array}{rr}\text { Pseudo } \mathrm{R}^{2} \\
\end{array}$ & 0.27 & 0.25 & 0.26 & 0.25 \\
\hline Impact of trade on growth Short run & 0.21 & 0.08 & 0.06 & 0.08 \\
\hline Long run & 2.62 & 1.33 & 1.00 & 0.83 \\
\hline Omitted ( $p$-value) & 0.00 & 0.94 & 0.00 & 0.00 \\
\hline
\end{tabular}

Notes:

See notes for Table 5 . 
Table 6b. Two-Stage Quantile Regressions with Interaction Terms (75th Quantile) Dependent variable: per-capita real GDP growth (75th quantile)

\begin{tabular}{|c|c|c|c|c|}
\hline & $(1)$ & $(2)$ & (3) & $(4)$ \\
\hline Real GDP(-1) & $\begin{array}{l}-0.06 \text { *** } \\
(-5.40)\end{array}$ & $\begin{array}{l}-0.05 * * * \\
(-4.74)\end{array}$ & $\begin{array}{l}-0.05 * * * \\
(-5.20)\end{array}$ & $\begin{array}{l}-0.05 \text { *** } \\
(-5.39)\end{array}$ \\
\hline Investment share & $\begin{array}{r}0.06 \\
(3.53)\end{array}$ & $\begin{array}{l}0.06 \text { *** } \\
(4.21)\end{array}$ & $\begin{array}{l}0.06 \text { *** } \\
(4.12)\end{array}$ & $\begin{array}{l}0.06 \text { *** } \\
(3.76)\end{array}$ \\
\hline Government Balance & $\begin{array}{r}0.1 \\
(0.66)\end{array}$ & $\begin{array}{r}0.22 \\
-1.68\end{array}$ & $\begin{array}{r}0.15 \\
(1.24)\end{array}$ & $\begin{array}{r}0.17 \\
(1.42)\end{array}$ \\
\hline Population growth & $\begin{array}{l}-0.05 * * * \\
(-4.08)\end{array}$ & $\begin{array}{l}-0.05 * * * \\
(-3.91)\end{array}$ & $\begin{array}{l}-0.05 * * * \\
(-4.09)\end{array}$ & $\begin{array}{l}-0.05 \text { *** } \\
(-4.02)\end{array}$ \\
\hline Terms of trade growth & $\begin{array}{r}0.00 \\
(0.22)\end{array}$ & $\begin{array}{r}0.00 \\
(0.37)\end{array}$ & $\begin{array}{r}0.00 \\
(0.85)\end{array}$ & $\begin{array}{r}0.00 \\
(0.54)\end{array}$ \\
\hline Inflation & $\begin{array}{r}-0.02 \\
(-1.56)\end{array}$ & $\begin{array}{l}-0.02 * * \\
(-2.03)\end{array}$ & $\begin{array}{l}-0.02 * * \\
(-2.77)\end{array}$ & $\begin{array}{r}-0.02 \\
(-1.42)\end{array}$ \\
\hline Trade(openness from gravity) & $\begin{array}{l}0.11 * * \\
(2.75)\end{array}$ & $\begin{array}{l}0.03 * \\
(1.94)\end{array}$ & $\begin{array}{l}0.04 * * \\
(2.61)\end{array}$ & $\begin{array}{l}0.03 \text { ** } \\
(2.16)\end{array}$ \\
\hline Trade $\mathrm{x}$ investment share $(-1)$ & $\begin{array}{l}0.04 * * \\
(2.23)\end{array}$ & - & - & - \\
\hline Trade $\times$ Gvt balance $(-1)$ & - & $\begin{array}{r}-0.06 \\
(-0.67)\end{array}$ & - & - \\
\hline Trade $x$ Inflation(-1) & - & - & $\begin{array}{l}-0.01 * * \\
(-2.65)\end{array}$ & - \\
\hline Trade $\times$ TOT growth(-1) & - & - & - & $\begin{array}{r}0.00 \\
(0.06)\end{array}$ \\
\hline Investment share(-1) & $\begin{array}{r}0.05 \\
(1.26)\end{array}$ & $\begin{array}{l}-0.03 * \\
(1.89)\end{array}$ & $\begin{array}{l}-0.03 * * \\
(-2.03)\end{array}$ & $\begin{array}{r}-0.02 \\
(-1.31)\end{array}$ \\
\hline Government balance(-1) & $\begin{array}{r}-0.02 \\
(-0.17)\end{array}$ & $\begin{array}{r}-0.08 \\
(-0.58)\end{array}$ & $\begin{array}{r}0.02 \\
(0.25)\end{array}$ & $\begin{array}{r}-0.02 \\
(0.18)\end{array}$ \\
\hline Population growth(-1) & $\begin{array}{r}0.01 \\
(1.68)\end{array}$ & $\begin{array}{l}0.007 \\
(0.49)\end{array}$ & $\begin{array}{r}0.01 \\
(1.35)\end{array}$ & $\begin{array}{l}0.01 * \\
(1.75)\end{array}$ \\
\hline Terms of trade growth(-1) & $\begin{array}{r}0.02 \\
(1.28)\end{array}$ & $\begin{array}{l}0.02 * * \\
(1.97)\end{array}$ & $\begin{array}{r}0.02 \\
(1.65)\end{array}$ & $\begin{array}{r}0.02 \\
(0.55)\end{array}$ \\
\hline Inflation(-1) & $\begin{array}{r}0.01 \\
(0.92)\end{array}$ & $\begin{array}{r}0.01 \\
(0.82)\end{array}$ & $\begin{array}{r}-0.02 \\
(-1.25)\end{array}$ & $\begin{array}{r}0.01 \\
(0.92)\end{array}$ \\
\hline Trade(-1) (Openness from gravity(-1)) & $\begin{array}{r}0.00 \\
(0.07)\end{array}$ & $\begin{array}{r}-0.01 \\
(0.37)\end{array}$ & $\begin{array}{r}-0.01 \\
(-0.73)\end{array}$ & $\begin{array}{r}-0.01 \\
(-0.47)\end{array}$ \\
\hline Trade(-1) $x$ investment share $(-2)$ & $\begin{array}{r}0.01 \\
(0.49)\end{array}$ & - & - & - \\
\hline Trade(-1) x Gvt balance $(-2)$ & - & $\begin{array}{r}-0.00 \\
(-0.04)\end{array}$ & - & - \\
\hline Trade(-1) x Inflation(-2) & - & - & $\begin{array}{r}0.00 \\
-0.70\end{array}$ & - \\
\hline Trade(-1) x TOT growth(-2) & - & - & - & $\begin{array}{r}0.00 \\
(-0.70)\end{array}$ \\
\hline $\begin{array}{rr}\text { Pseudo } \mathrm{R}^{2} \\
\end{array}$ & 0.25 & 0.24 & 0.24 & 0.23 \\
\hline Impact of trade on growth Short run & 0.15 & 0.03 & 0.03 & 0.03 \\
\hline $\begin{array}{r}\text { Long run } \\
\text { Omitted }(p \text {-value })\end{array}$ & $\begin{array}{l}2.50 \\
0.04\end{array}$ & $\begin{array}{l}0.60 \\
0.62\end{array}$ & $\begin{array}{l}0.60 \\
0.00\end{array}$ & $\begin{array}{l}0.60 \\
0.91\end{array}$ \\
\hline
\end{tabular}

Notes:

See notes for Table 5 . 
Figure 1. Impact of trade on growth at different quantiles and $95 \%$ confidence interval.

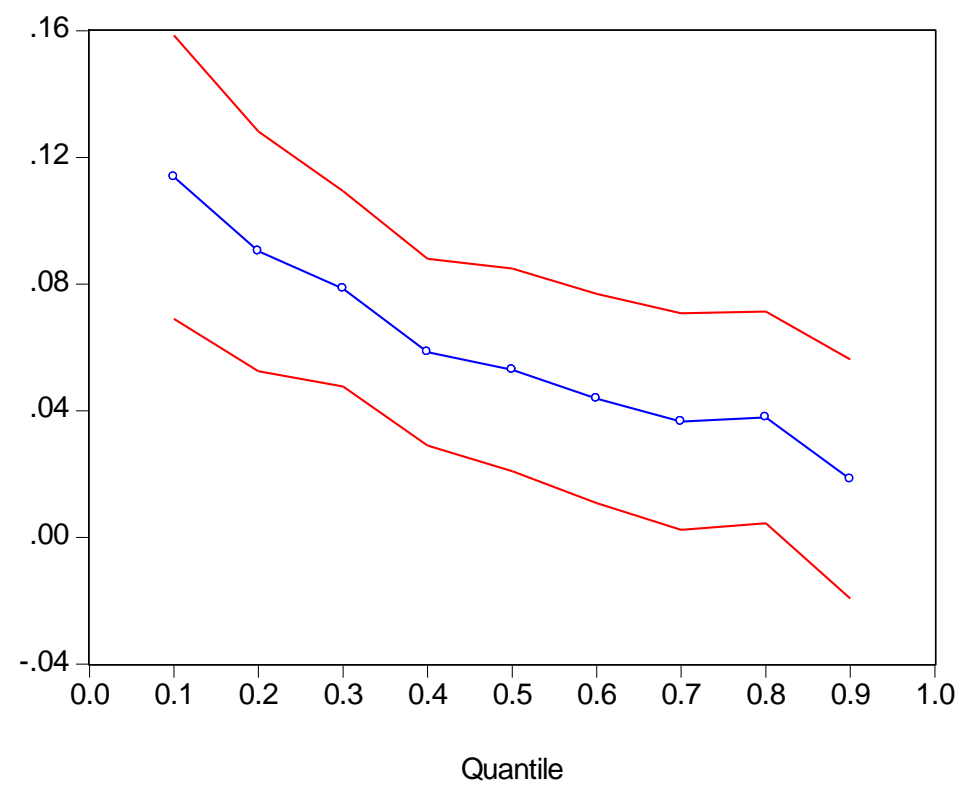


Figure 2. Growth conditional distribution (positive trade shock).

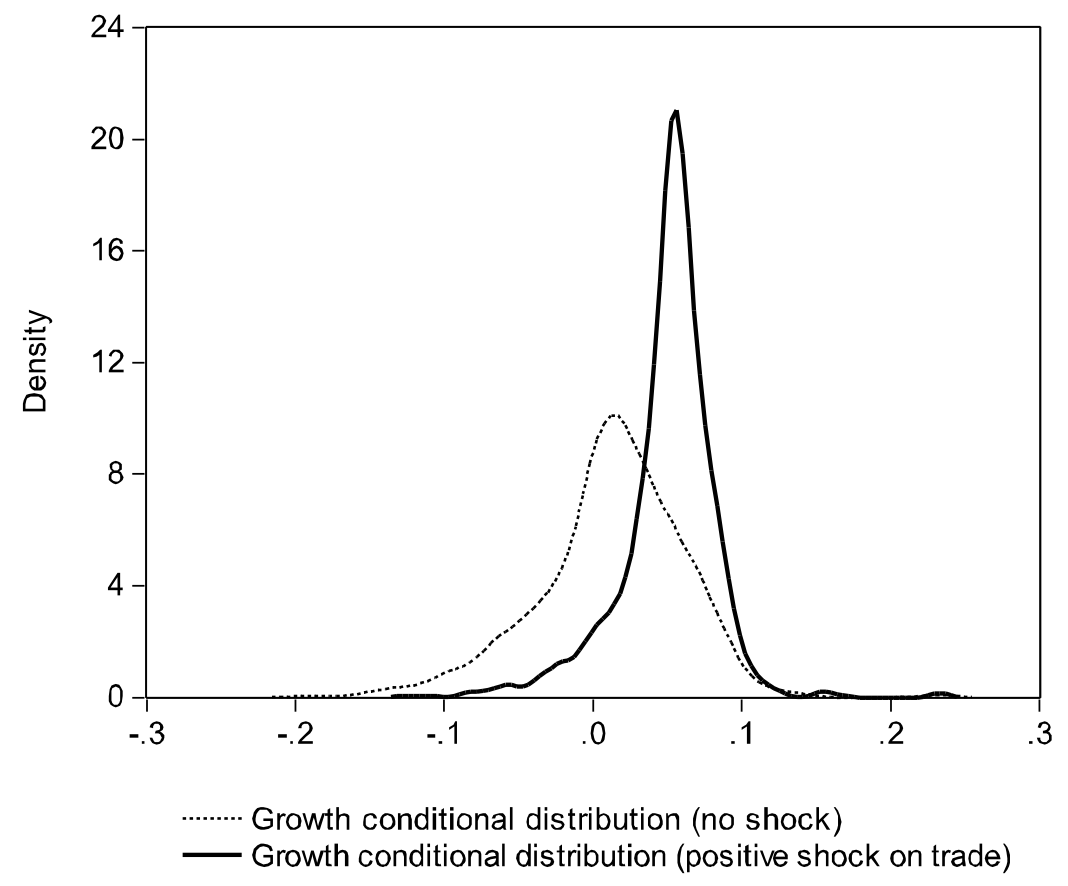


Figure 3. Growth conditional distribution (negative trade shock).

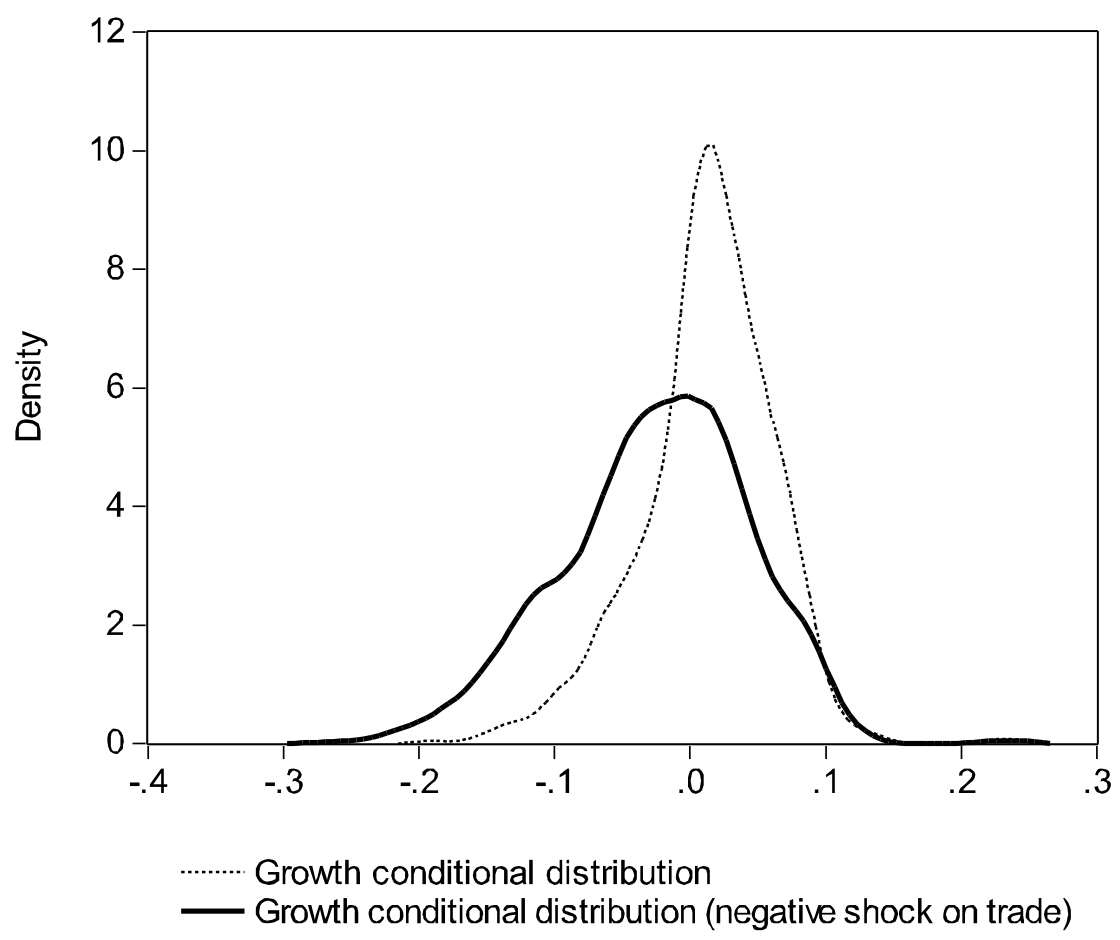




\section{Appendix A \\ Selection of the Control Variables}

This Appendix provides a summary of the BMA approach and presents briefly the calculated quantities and summary statistics used. Further details of the FLS (Fernández, Ley and Steel, 2001a) and SDM (Sala-í-Martin, Doppelhofer and Miller, 2004) can be found in the original papers. ${ }^{25}$

Suppose that the parameter space can be divided into $K$ regions (models) where $\theta$ is the quantity of interest. Let $D$ denote the data. Then Bayesian inference about $\theta$ is constructed using Bayesian Model Averaging (BMA), based on the posterior distribution:

$$
p(\theta \mid D)=\sum_{j=1}^{K} p\left(\theta \mid D, M_{j}\right) p\left(M_{j} \mid D\right)
$$

which follows by the law of total probability. Therefore, the full posterior distribution of $\theta$ is a weighted average of the posterior distributions under each model $\left(M_{1}, \ldots, M_{K}\right)$, where the weights are the posterior model probabilities $p\left(M_{j} \mid D\right)$.

Using Bayes' theorem, the posterior model probabilities are obtained using:

$$
p\left(M_{j} \mid D\right)=\frac{p\left(D \mid M_{j}\right) p\left(M_{j}\right)}{\sum_{l=1}^{K} p\left(D \mid M_{l}\right) p\left(M_{l}\right)}
$$

In the spirit of Bayesian inference, prior distributions need to be specified for the parameters $\theta_{k}$, and the models $M_{j}$, the specification of which differs between FLS and SDM. Assuming that we have $k^{*}$ variables, there are $K=2^{k^{*}}$ possible sampling models, so the space of all possible models is $\mathcal{M}=M_{j}: j=1, \ldots, 2^{k^{*}}$. When there is no preference for a specific model $p\left(M_{1}\right)=p\left(M_{2}\right)=\ldots=p\left(M_{K}\right)=\frac{1}{K}$, which is the specification in FLS. However, SDM assume that the model probabilities are not equal: assuming that each variable has an equal inclusion probability, the prior probability for model $M_{j}$ is:

$$
p M_{j}=\left(\frac{\bar{k}}{k^{*}}\right)^{k_{j}}\left(1-\frac{\bar{k}}{k^{*}}\right)^{k^{*}-k_{j}}
$$

where $k^{*}$ is the total number of regressors, $\bar{k}$ is the researcher's prior about the size of the model, $k_{j}$ is the number of included variables in model $M_{j}$, and $\frac{\bar{k}}{k^{*}}$ is the prior inclusion probability for each variable.

\footnotetext{
${ }^{25}$ We thank the authors for making their Fortran and Gauss codes available. See the Journal of Applied Econometrics Data Archive for FLS, and http://www.econ.cam.ac.uk/faculty/doppelhofer/ for SDM.
} 
Defining parameter priors in the case of SDM reduces to defining only $\bar{k}$. That is the only prior that is arbitrarily specified in the simulations, so robustness checks of the results are estimated by changing the value of this parameter. For this reason, we estimate our simulations with values of $\bar{k}=5,8,11,15$. On the other hand, FLS define priors for the parameters that are common to all models, namely the intercept, the scale parameter, and the slope coefficients. For the intercept and the scale parameter improper priors are assumed, while for the slope parameters we experiment with a variety of g-priors (specifically 1-9) as discussed in Fernández et al. (2001b).

Posterior densities can be calculated for $\theta$ using (1.1). Further, using (1.2) we can estimate the posterior inclusion probability of a variable. It is the sum of all posterior probabilities of all the regressions including the specific variable (regressor), and it serves as a ranking measure to see how much the data favors the inclusion of a variable in the regression. It is calculated as:

$$
P(\text { inclusion })=p\left(\theta_{k} \neq 0 \mid D\right)=\sum_{\theta_{k} \neq 0} p\left(M_{j} \mid D\right)
$$

If $p\left(\theta_{k} \neq 0 \mid D\right)>p\left(\theta_{k} \neq 0\right)=\frac{\bar{k}}{k^{*}}$ then the variable has high marginal contribution to the regression model.

Next, conditional on a variable's inclusion, we compute the sign certainty probability, a measure of the robustness of the sign of the coefficient. It estimates the probability that (conditional on inclusion) the coefficient is on the same side of zero as its mean and is calculated as:

$$
\begin{aligned}
P(\text { sign certainty }) & =p\left[\begin{array}{lll}
\operatorname{sgn} \theta_{k}=\operatorname{sgn} E & \theta_{k}|D| D, \theta_{k} \neq 0
\end{array}\right] \\
& =\sum_{j=1}^{2^{k^{*}}} p \quad M_{j} \mid D \quad p\left[\begin{array}{lll}
\operatorname{sgn} \theta_{k}=\operatorname{sgn} E & \left.\theta_{k}|D| M_{j}, D\right]
\end{array}\right.
\end{aligned}
$$

We base our robustness estimations on the inclusion probability and the sign certainty. ${ }^{26}$

In particular, we proceed as follows. From a set of 22 or 24 potential regressors we apply both the FLS and SDM estimations to derive $P$ (inclusion) and $P$ (sign certainty). This is repeated for nine values of g-priors for FLS and five values of $\bar{k}(\bar{k}=5,8,11,15)$ in the case of SDM. Then results are "aggregated" from both simulations and then summarized using our specified rule where a variable is identified as "robust" if $P$ (inclusion) $\geq 0.50$ and $P($ sign $) \geq 0.90$. Finally, we combine results from all three simulations to arrive at the set of robust growth determinants used in (1).

\footnotetext{
${ }^{26}$ In addition, conditional means and variances may be computed, as discussed in FLS and SDM. We are not interested in inference based on BMA per se, so we only focus on these two measures.
} 
Appendix A, Table 7: List of Variables Used in the Growth Regressions

Possible Simulations Using 22-24 Regressors

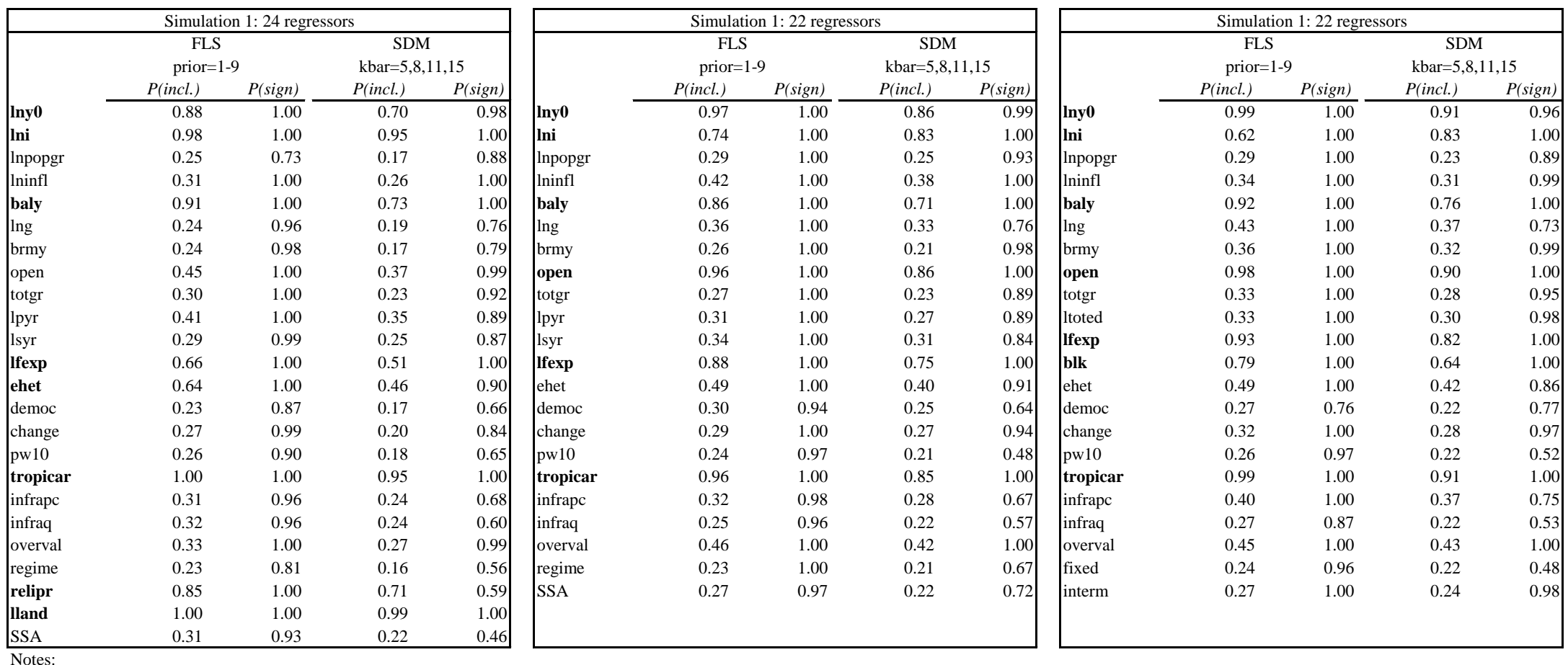

. For a list of regressors and their definitions and sources see Appendix B.

2. Variables in bold are classified as "robust" using the authors' defined criterion for robustness: $\mathrm{P}($ sign $) \geq 0.90$ and $\mathrm{P}($ inclusion $) \geq 0.50$

3. Each of the simulations 1-3 were estimated using several priors. For FLS, priors 1 through 9 were used as defined in Fernandez et al. (2001b). For SDM, priors of kbar=5, 8, 11, 15 with kbar as

defined in Sala-í-Martin et al. (2004). 
Appendix B: List of Variables Used in the Growth Regressions

\begin{tabular}{|c|c|c|}
\hline Variable & Definition & Source \\
\hline \multicolumn{3}{|l|}{ Dependent Variable } \\
\hline DIFFY & Logarithm of real GDP per capita (1996 US dollars at PPP) & Penn World Table 6.1 (Heston et al., 2002) \\
\hline \multicolumn{3}{|c|}{ Explanatory Variables } \\
\hline LNYO & Logarithm of initial real GDP per capita (1996 US dollars at PPP) & Penn World Table 6.1 (Heston et al., 2002) \\
\hline \multicolumn{3}{|c|}{ Solow determinants } \\
\hline LNI & Logarithm of real investment as ratio to GDP (1996 US dollars at PPP) & Penn World Table 6.1 (Heston et al., 2002) \\
\hline LNNPOPGR & Logarithm of annual population growth rate plus 0.05 & Penn World Table 6.1 (Heston et al., 2002) \\
\hline \multicolumn{3}{|c|}{ Human capital (Augmented Solow) } \\
\hline LPYR & Logarithm of average stock of years of primary education & Barro and Lee (2000) \\
\hline LSYR & Logarithm of average stock of years of secondary education & Barro and Lee (2000) \\
\hline \multicolumn{3}{|c|}{ Macroeconomic stability } \\
\hline LNINFL & Logarithm of one plus the inflation rate. & IFS (IMF, 2008a) \\
\hline BALY & Government balance as share of GDP, current LCU & World Economic Outlook (IMF, 2008b) \\
\hline LNG & Logarithm of real government consumption as ratio to GDP & Penn World Table 6.1 (Heston et al., 2002) \\
\hline \multicolumn{3}{|c|}{ Financial development } \\
\hline BRMY & Ratio of broad money to GDP. & World Economic Outlook (IMF, 2008b) \\
\hline \multicolumn{3}{|l|}{ Trade regime } \\
\hline OPEN & Exports plus Imports as share of GDP (1996 US dollars at PPP) & Penn World Table 6.1 (Heston et al., 2002) \\
\hline \multicolumn{3}{|c|}{ External environment } \\
\hline TOTGR & Terms of trade (goods and services) growth & World Economic Outlook (IMF, 2008b) \\
\hline \multicolumn{3}{|c|}{ the } \\
\hline LFEXP & Life expectancy at birth (total) & World Development Indicators (World Bank, 2008) \\
\hline \multicolumn{3}{|c|}{ Internal environment/resources } \\
\hline LLAND & Logarithm of arable land per capita, hectares, average over five years & World Development Indicators (World Bank, 2008) \\
\hline EHET & Ethnic heterogeneity & Sambanis (2000) \\
\hline ELFO & Updated index of ethnolinguistics fractionalization & Sambanis (2000) \\
\hline INFRAQ & Indicator of infrastructure quality & Calderón and Servén $(2004,2008)$ \\
\hline INFRAPC & Indicator of infrastructure stock & Calderón and Servén $(2004,2008)$ \\
\hline RELIPR & Relative investment price level (PI/PC) (1996 US dollars at PPP) & Penn World Table 6.1 (Heston et al., 2002) \\
\hline \multicolumn{3}{|l|}{ Corruption/War } \\
\hline BLK & Ratio of black market rate and official exchange rate minus one & Easterly and Sewadeh (2001) \\
\hline PW10 & Incidence of civil war in the last 10 years & Sambanis (2000) \\
\hline \multicolumn{3}{|c|}{ Institutions/governance } \\
\hline DEMOC & Aggregate index of democracy & Polity IV (Marshall and Jaggers, 2008) \\
\hline CHANGE & Annual change in the Polity index & Polity IV (Marshall and Jaggers, 2008) \\
\hline \multicolumn{3}{|c|}{ Geography/Physical Factors } \\
\hline TROPICAR & $\%$ Land area in geographical tropics & Gallup et al. (1999) \\
\hline \multicolumn{3}{|c|}{ Dummy variables } \\
\hline SSA & Sub-Saharan Africa Dummy & IMF classification (IMF, 2008b) \\
\hline \multicolumn{3}{|c|}{ Exchange rate regime } \\
\hline OVERVAL & Index of overvaluation/undervaluation based on ppp & Author's calculation \\
\hline REGIME & IMF de facto fine classification & Author's calculation \\
\hline FIXED & IMF de facto fine classification & Author's calculation \\
\hline INTERM & IMF de facto fine classification & Author's calculation \\
\hline FLOAT & IMF de facto fine classification & Author's calculation \\
\hline
\end{tabular}


Appendix C: Gravity Model Estimations

\begin{tabular}{|c|c|c|c|c|c|c|}
\hline $\begin{array}{l}\text { Estimation: } \\
\text { Specification: }\end{array}$ & $\begin{array}{c}\text { OLS } \\
(1)\end{array}$ & $\begin{array}{l}\text { CFE } \\
(2)\end{array}$ & $\begin{array}{l}\text { CPFE } \\
\text { (3) }\end{array}$ & $\begin{array}{l}\text { HT1 } \\
(4)\end{array}$ & $\begin{array}{c}\text { HT2 } \\
(5)\end{array}$ & \\
\hline Currency union & $\begin{array}{l}0.36 \text { ** } \\
(0.15)\end{array}$ & $\begin{array}{l}0.42 \text { *** } \\
(0.15)\end{array}$ & $\begin{array}{l}0.09 * \\
(0.06)\end{array}$ & $\begin{array}{l}0.14 * * \\
(0.07)\end{array}$ & $\begin{array}{r}0.10 \\
(0.07)\end{array}$ & \\
\hline Log distance & $\begin{array}{l}-1.28 * * * \\
(0.02)\end{array}$ & $\begin{array}{l}-1.56 * * * \\
(0.02)\end{array}$ & & $\begin{array}{l}-2.33 * * * \\
(0.08)\end{array}$ & $\begin{array}{r}-3.58 \\
(0.50)\end{array}$ & $* * *$ \\
\hline Log product real GDP & $\begin{array}{l}1.12 \text { *** } \\
(0.01)\end{array}$ & $\begin{array}{l}0.34 * * * \\
(0.07)\end{array}$ & $\begin{array}{l}0.85 * * * \\
(0.07)\end{array}$ & $\begin{array}{l}1.18 \text { *** } \\
(0.02)\end{array}$ & $\begin{array}{r}0.92 \\
(0.02)\end{array}$ & $* * *$ \\
\hline Log product real GDP/capita & $\begin{array}{r}0.00 \\
(0.01)\end{array}$ & $\begin{array}{l}0.53 \text { *** } \\
(0.07)\end{array}$ & $\begin{array}{l}0.14 \text { ** } \\
(0.06)\end{array}$ & $\begin{array}{l}-0.06 * * * \\
(0.02)\end{array}$ & $\begin{array}{r}0.10 \\
(0.02)\end{array}$ & $* * *$ \\
\hline Common language & $\begin{array}{l}0.49 \text { *** } \\
(0.05)\end{array}$ & $\begin{array}{l}0.48 \text { *** } \\
(0.05)\end{array}$ & & $\begin{array}{l}0.48 * * * \\
(0.07)\end{array}$ & $\begin{array}{r}0.31 \\
(0.28)\end{array}$ & \\
\hline Common land border & $\begin{array}{l}0.69 \text { *** } \\
(0.12)\end{array}$ & $\begin{array}{l}0.47 \text { *** } \\
(0.12)\end{array}$ & & $\begin{array}{l}-0.81 * * * \\
(0.23)\end{array}$ & $\begin{array}{r}-3.25 \\
(1.18)\end{array}$ & $* * *$ \\
\hline Free trade agreement (FTA) & $\begin{array}{l}1.25 \text { *** } \\
(0.10)\end{array}$ & $\begin{array}{l}0.59 \text { *** } \\
(0.09)\end{array}$ & $\begin{array}{l}0.25 * * * \\
(0.05)\end{array}$ & $\begin{array}{l}0.26 \text { *** } \\
(0.04)\end{array}$ & $\begin{array}{r}0.26 \\
(0.03)\end{array}$ & $* * *$ \\
\hline Number landlocked in the pair & $\begin{array}{l}-0.32 \text { *** } \\
(0.03)\end{array}$ & $\begin{array}{l}-3.49 * * * \\
(0.37)\end{array}$ & & $\begin{array}{l}-0.40 * * * \\
(0.05)\end{array}$ & $\begin{array}{r}-0.69 \\
(0.18)\end{array}$ & $* * *$ \\
\hline Number islands in the pair & $\begin{array}{l}0.13 \text { *** } \\
(0.04)\end{array}$ & $\begin{array}{r}-0.58 \\
(518.20)\end{array}$ & & $\begin{array}{l}0.61 \text { *** } \\
(0.06)\end{array}$ & $\begin{array}{r}0.93 \\
(0.28)\end{array}$ & $* * *$ \\
\hline Log product of areas & $\begin{array}{l}-0.07 * * * \\
(0.01)\end{array}$ & $\begin{array}{l}0.39 \text { *** } \\
(0.03)\end{array}$ & & $\begin{array}{l}-0.03 * \\
(0.02)\end{array}$ & $\begin{array}{r}0.15 \\
(0.04)\end{array}$ & $* * *$ \\
\hline Common colonizer & $\begin{array}{l}0.85 \text { *** } \\
(0.07)\end{array}$ & $\begin{array}{l}0.83 \text { *** } \\
(0.07)\end{array}$ & & $\begin{array}{l}0.73 \text { *** } \\
(0.09)\end{array}$ & $\begin{array}{r}0.24 \\
(0.37)\end{array}$ & \\
\hline Current colony & $\begin{array}{r}0.26 \\
(0.26)\end{array}$ & $\begin{array}{r}0.71 \\
(0.74)\end{array}$ & $\begin{array}{r}0.18 \\
(0.39)\end{array}$ & $\begin{array}{r}0.16 \\
(0.27)\end{array}$ & $\begin{array}{r}0.17 \\
(0.27)\end{array}$ & \\
\hline Ever colony & $\begin{array}{l}1.32 \text { *** } \\
(0.13)\end{array}$ & $\begin{array}{l}1.38 \text { *** } \\
(0.13)\end{array}$ & & $\begin{array}{l}1.41 \text { *** } \\
(0.24)\end{array}$ & $\begin{array}{r}1.85 \\
(0.92)\end{array}$ & $* *$ \\
\hline Same nation & $\begin{array}{l}1.95 \text { *** } \\
(0.43)\end{array}$ & $\begin{array}{r}1.64 \\
(0.85)\end{array}$ & & $\begin{array}{r}2.69 \\
(1.73)\end{array}$ & $\begin{array}{r}3.43 \\
(6.60)\end{array}$ & \\
\hline Constant & $\begin{array}{l}-26.07 * * * \\
(0.32)\end{array}$ & $\begin{array}{rl}-5.03 & * * \\
(2.02) & \\
\end{array}$ & $\begin{array}{l}-28.01 * * * \\
(2.30)\end{array}$ & $\begin{array}{l}-20.79 * * * \\
(0.83)\end{array}$ & $\begin{array}{r}-4.89 \\
(3.79) \\
\end{array}$ & \\
\hline Observations & 221269 & 221269 & 221269 & 221269 & 221269 & \\
\hline $\begin{array}{l}\text { Number of pairid } \\
\text { R-squared }\end{array}$ & 0.70 & 0.75 & $\begin{array}{r}13431 \\
0.10\end{array}$ & 13431 & 13431 & \\
\hline Hausman HT1 vs RE ( $p$-value) & & & & & 0.00 & \\
\hline Hausman FE vs HT1 ( $p$-value) & & & & & 0.76 & \\
\hline Hausman HT2 vs RE ( $p$-value) & & & & 0.00 & & \\
\hline Hausman FE vs HT2 ( $p$-value) & & & & 0.63 & & \\
\hline Hausman FE vs RE ( $p$-value) & & & & 0.00 & 0.00 & \\
\hline
\end{tabular}

Notes: Authors' calculations.

1. Robust standard errors in parentheses. $* * *$ significant at $1 \%$, ** significant at $5 \%$, * significant at $10 \%$.

2. Instuments for HT estimation are: for HT1: endogenous (cu ldist lrgdp lrgdppc) and HT1: endogenous (cu fta ldist).

3. Time effects included in the regressions. CFE, CPFE, and HT stand for country fixed effects, country pair fixed effects, and Hausman-Taylor, respectively.

4. Hausman $p$-values represent test $p$-values from sequential testing to select among FE vs. RE vs. HT based on pre-test estimator of Baltagi et al (2003). 


\section{Appendix D: List of countries}

\begin{tabular}{|c|c|}
\hline Region & Counties \\
\hline Africa (27) & $\begin{array}{l}\text { Algeria, Benin, Botswana, Burkina Faso, Cameroon, Côte d'Ivoire, Egypt, Ethiopia, Ghana, Mauritius, } \\
\text { Kenya, Madagascar, Malawi, Mali, Morocco, Mozambique, Namibia, Niger, Nigeria, Senegal, South Africa, } \\
\text { Sudan, Tanzania, Togo, Tunisia, Uganda, Zambia. }\end{array}$ \\
\hline Asia and Pacific (14) & $\begin{array}{l}\text { Bangladesh, China, South Korea, India, Indonesia, Malaysia, Nepal, Pakistan, Papua New Guinea, } \\
\text { Philippines, Singapore, Sri-Lanka, Thailand, Vietnam. }\end{array}$ \\
\hline Central and Latin America & $\begin{array}{l}\text { Argentina, Bahamas, Bolivia, Brazil, Chile, Colombia, Costa Rica, Dominican Republic, El Salvador, } \\
\text { Ecuador, Guatemala, Guyana, Honduras, Jamaica, Mexico, Nicaragua, Panama, Paraguay, Peru, Trinidad } \\
\text { and Tobago, Uruguay, Venezuela. }\end{array}$ \\
\hline Arab and Middle East (9) & $\begin{array}{l}\text { Bahrain, Iran Islamic Republic, Jordan, Kuwait, Lebanon, Oman, Saudi Arabia, Syrian Arab Republic, } \\
\text { Yemen. }\end{array}$ \\
\hline Europe (3) & Albania, Armenia, Republic of Moldova. \\
\hline
\end{tabular}

